University of Konstanz

Department of Economics

\title{
Semiparametric Decomposition of the Gender Achievement Gap: An Application for Turkey
}

Z. Eylem Gevrek and Ruben R. Seiberlich

Working Paper Series

2012-32 


\title{
Semiparametric Decomposition of the Gender Achievement Gap: An Application for Turkey
}

\author{
Z. Eylem Gevrek* \\ Ruben R. Seiberlich \\ University of Konstanz \\ University of Konstanz
}

\begin{abstract}
Using the data from the 2006 Programme for International Student Assessment (PISA), this study sheds light on the gender gap in mathematics and science achievement of 15-year-olds in Turkey. We apply a semiparametric Oaxaca-Blinder (OB) decomposition to investigate the gap. This technique relaxes the parametric assumptions of the standard OB decomposition, accounts for the possible violation of the common support assumption and allows us to explore the gender test score gap not only at the mean but also across the entire distribution of test scores. Our findings provide evidence that the failure to recognize the common support problem leads to the underestimation of the part of the gap attributable to observable characteristics. We find that girls outperform boys in science while the gap is not statistically significant in math. School characteristics are the most important observable characteristics in explaining the gap. We also find that the gender test score gap changes across the distribution.
\end{abstract}

JEL classification: I21, C14

Keywords: Gender test score gap, semiparametric decomposition, propensity score matching

\footnotetext{
${ }^{*}$ Corresponding author. Department of Economics, Box D124, University of Konstanz, 78457 Konstanz, Germany. Phone ++49-7531-88-4183, Fax -4450, Email: zahide.gevrek@uni-konstanz.de.
} 


\section{Introduction}

Gender inequalities in educational performance have been the subject of much research for many decades. Promoting gender equality in education is an important policy goal especially in developing countries as it is associated with greater equality in employment outcomes, low infant mortality rates, a decrease in the number of early marriages and better investments in education and health of future generations (OECD (2010)). Using the data from the 2006 Programme for International Student Assessment (PISA), this study explores the gender gap in mathematics and science achievement of 15-year-olds in Turkey. We apply a semiparametric Oaxaca-Blinder (OB) decomposition to investigate the gap.

The exploration of gender test score gap is important for the following reasons. First, the recent research on the economic impact of human capital investment underlines the prime importance of educational quality over pure schooling attainment (Hanushek (2008)). Social scientists use international tests of students' performance in cognitive skills such as mathematics and science as a proxy for education quality. Mulligan (1999) and Murnane, Willett, Duhaldeborde, and Tyler (2000) show that mathematics test score in high school has a significant effect on annual earnings. Since math, and science skills are highly valued in the labor market, understanding the gender patterns in these subject fields allows us to gain insight into the gender wage gap and differential education and labor market choices across genders. For example, if girls lag behind boys in terms of the accumulation of math skills in childhood and adolescence, they are less likely than boys to choose science, technology and engineering as a field of study at tertiary level, promoting gender inequality in employment opportunities such as the underrepresentation of women in math-intensive fields. Second, using data from the international student achievement tests, empirical growth research documents a significant impact of the qual-

ity of education on economic growth (Hanushek and Kimko (2000); Jamison, Jamison, and Hanushek (2007)). Moreover, Hanushek and Hitomi (2008) provide evidence that 
educational quality is closely related to school attainment in the developing countries. Thus, educational policies aimed to improve quality of education also help meet goals for educational attainment.

The contribution of this paper to the literature is threefold. First, although OaxacaBlinder decomposition (Oaxaca (1973); Blinder (1973)) has been widely used to examine discrimination in the labor market, the application of this methodology in the economics of education is quite recent. It has been applied to examine the test score gap between countries (Ammermüller (2007); Botezat and Seiberlich (2011)), schools (private versus public) (Duncan and Sandy (2007); Krieg and Storer (2006)) and ethnic groups (indigenous versus non-indigenous) (Sakellariou (2008); McEwan (2004)). There are only two studies that use the decomposition to analyze the gender test score gap. Sohn (2010) uses an aggregate quantile decomposition to analyze the gender mathematics gap in primary school in the USA while Hille (2011) use a detailed decomposition at mean to study the gender gap in mathematics in French primary school.

Our decomposition method has several advantages over the standard OB decomposition. The semiparametric decomposition relaxes the parametric functional form assumption of the standard OB decomposition. It provides useful information on the gender test score gap not only at the mean but also across the entire distribution of test scores. In addition, the standard OB decomposition ignores the common support problem. Nopo (2008) shows that failure to account for the problem of lack of common support leads to systematically upward-biased estimates of the unexplained part. In the semiparametric decomposition, on the other hand, counterfactual outcomes are computed only for the common support subpopulation. The rationale behind this empirical strategy ensures that female and male observations that are actually comparable in terms of their observed characteristics are matched. The semiparametric matching method makes it possible to estimate the counterfactual outcome for each individual separately, allowing us to account for arbitrary individual effect heterogeneity.

Second, there are a number of studies that examine gender gap in educational at- 
tainment in Turkey 1 However, studies on the quality of education, which is measured by achievement on standardized tests, basically analyze the determinants of academic achievement without paying sufficient attention to the causes of the gender test score gap 2 To the best of our knowledge, this is the first study that rigorously examines the gender test score gap in Turkey using a semiparametric OB decomposition. Moreover, Turkey is an interesting case to study as it has the largest average gender test score gap in science and one of the smallest gap in mathematics among OECD countries 3

Third, as science literacy was the subject area assessed in depth in PISA 2006, students were asked about different aspects of how they view science. The PISA 2006 contains questions looked at students' general and personal value of science, their interest and enjoyment of science, plus their self-concept of their own abilities in science and whether they are motivated to use science in the future. Taking advantage of this information, we construct two indexes, namely the index of students' general level of beliefs in their academic abilities in science and the index of motivation in science. We expect that the higher levels on each index, the higher the student's performance in science and math. Although, these indexes are subjective measures of motivation and ability, they allow us to control for potentially endogenous effects at least to some extent.

The semiparametric OB decomposition results can be summarized as follows. The

\footnotetext{
${ }^{1}$ Tansel (2002) uses data from the 1994 Household Budget Survey to investigate determinants of the gender gap in educational attainment. Utilizing data from the 1988 and 2006 Household Labor Force surveys, Hisarciklılar, McKay, and Wright (2010) examine how the gender gap in educational attainment changed over an 18-year period during which Turkey launched the educational modernization program. Focusing on undergraduate students in a large public university in Turkey, Dayioğlu and TürütAşik (2007) examine gender gaps in university entrance exam scores and academic performance. Smits and Hosgor (2006) study the impact of family background variables on participation in primary and secondary education of children and point to the importance of mother's education especially in primary participation of girls. Dayioğlu, Kirdar, and Tansel (2009) investigate the effect of sibling composition on the gender gap in school enrollment in urban Turkey.

${ }^{2}$ Dincer and Uysal (2010) examine determinants of student achievement in science using data from the 2006 PISA. Aypay, Erdoğan, and Sözer (2007) aim to answer the same research question by utilizing data from the 1999 Trends in Mathematics and Science Study (TIMMS). Erberber (2009) uses the 2007 TIMMS to investigate factors associated with Turkey's regional differences in science achievement.

${ }^{3}$ According to the PISA 2006 test results, the mean gender test score gap in science across OECD countries ranges between 11.9 score points in favor of girls in Turkey and 10.06 score points in favor of boys in the UK. In math, boys outscore girls in all countries except Iceland. Turkey with 4.48 score points on the low end while Austria has the highest gap with 22.61 score points.
} 
mean test score gap is 15.1 points in favor of girls in science while it is not statistically significant in math. Girls possess more of the characteristics associated with high science scores. School characteristics are the most important observable characteristics in explaining the gap. Our findings suggest that ignoring the common support problem causes the underestimation of the part of the gap attributable to observable characteristics. Moreover, gender test score gap shows heterogenous pattern across the test score distribution. We find that in science, the gap favoring girls is statistically significant until the top quantile and the largest gap occurs at the $50^{\text {th }}$ quantile. In math, the gap is statistically significant only at the top quantile where boys outperform girls.

This study is organized as follows. The next section reviews studies exploring the gender test score gap and provides background information on the education system in Turkey. Section 3 describes the data and variables used in the empirical analysis. Section 4 introduces the econometric model and discusses the identification strategy. Section 5 presents results while Section 6 concludes.

\section{Background and Literature}

\subsection{Factors Influencing Gender Test Score Gap: Nature versus Nurture}

There has been much interest in examining the link between the structure of brain and gender differences in educational outcomes. The proponents of biological theories argue that gender differences in brain composition, hormone levels and spatial ability produce a gap in achievement. Uncovering anatomical, chemical and functional differences between the brains of men and women, Cahill (2012) provides evidence that how these genderbased variations relate to differences in male and female cognition. Davison and Susman (2001) look at the relationship between cognitive ability and hormone levels. They investigate whether higher levels of testosterone are associated with better spatial skills by 
assessing testosterone levels of boys and girls aged between 9 and 14 years old at three test session every six months. The results show positive relations between spatial scores and testosterone for boys at all three sessions whereas for girls at the third session. Brosnan (2006) points out that the effects of testosterone on spatial performance cannot be generalized at the right tail of the spatial distribution. Kucian, Loenneker, Dietrich, Martin, and Von Aster (2005) examine whether males and females differ in brain activation and performance patterns when solving number-related tasks. They observe different activation patterns between males and females in tasks that require the use of complex problem solving strategies. Ceci, Williams, and Barnett (2009) give an extensive review of studies focusing on biological explanations and underscore that biological evidence provided by research in this domain is inconsistent and sometimes contradictory. In our study, we cannot test hypotheses based on biological explanations due to data limitations.

The other strand of the literature emphasizes sociological and environmental factors as the cause of the gap. One of the most important sociological arguments attributes the gender gap in educational achievement to stereotypical thinking such as believing that girls just cannot do math, language is for girls and math is for boys. Investigating geographic differences in gender test score gap in the U.S., Pope and Sydnor (2010) find that there is a large and statistically significant variation in the gender ratios of $8^{\text {th }}$ graders scoring at the top percentiles of the National Assessment Educational Process (NAEP) across states and census divisions 4 They also find that in areas where men and women are viewed as more equal, gender disparities are smaller in both stereotypically male-dominated tests of math and science and stereotypically female-dominated tests of reading. Fryer and Levitt (2010) show that parents have lower math expectations for their daughters. They test whether these parental gender stereotypes can explain why girls fall behind in math. To capture the parental expectation effect, they also include an indicator variable for having a mother who works in math-related professions in their regression. The findings

\footnotetext{
${ }^{4}$ The NAEP is a series of standardized tests in subjects such as math, science and reading. The test is taken by a sample of public school students in grades 4, 8, and 12 throughout the U.S.
} 
indicate that parental expectations do not have a significant impact on the gender math gap. However, Tiedemann (2000) and Jacobs and Eccles (1992) provide evidence that parents' gender stereotyped beliefs about their children's competence in math (i.e. math is a male domain) influence children's self-perceptions of ability in math and hence their math achievement. Moreover, Carrell, Page, and West (2009) examine the impact of a teacher's gender on students' performance in math and science classes. Having a female math or science teacher has a significant effect on female students' performance in math and science while professor gender has little impact on male students. The effect is more pronounced for female students with very strong math skills.

Guiso, Monte, Sapienza, and Zingales (2008) examine gender test score gaps in mathematics and reading across 40 countries using data from the 2003 PISA. They find that boys, on average, outperform girls by 2 percent in mathematics. Moreover, the gap virtually disappears in more gender-equal countries such as Norway and Sweden. The gender gap is reversed in reading. Girls, on average, score 6,6 percent higher than boys. However, more gender-equal cultures are associated with an increase in the reading gap in favor of girls. For example, girls' reading score average is 25.1 higher than that of boys in Turkey while in Iceland it is 61 higher 5 Therefore, their findings point to the importance of culture in explaining the gender test score gap.

There exists a substantial body of research on the importance of family background variables such as parental education, family income and educational resources available at home on student performance (Lara-Cinisomo, Pebley, Vaiana, Maggio, Berends, and Lucas (2004); Carneiro and Heckman (2003); Hanushek and Luque (2003); Wößmann (2003)). In the literature, there is a long-lasting debate over the relative importance of family background and school-related factors on students' achievement (NonoyamaTarumi and Willms (2010)). After taking account of family background factors, Fuchs and Woessmann (2007) and Wößmann (2009) examine the impact of school-related factors

\footnotetext{
${ }^{5}$ They use several measures for the gender equality of a country such as The World Economic Forum's Gender Gap Index (GGI). Larger values of GGI correspond to a better average position of women in society. Turkey with 0.59 GGI score is on the low end while Iceland with 0.78 is on the high end.
} 
on student achievement across countries using the PISA data sets. They show that both family socioeconomic status variables and school institutional factors such as whether the school is public or private and school academic selectivity have significant impacts on student achievement. However, evidence on school resources such as class size and student-teacher ratio is mixed. Hanushek and Luque (2003) points to inconsistency of the estimated effect of school resources in the literature.

In sum, it is difficult to address the question of nature versus nurture related to the gender test score gap due to interactions between biological and environmental factors

\subsection{Secondary Education in Turkey}

Formal education in Turkey consists of the institutions of preschool education, primary education, secondary education and higher education. Preschool education is voluntary. Eight years of primary education, which used to be five years until 1997, is compulsory for all Turkish citizens and is free of charge in public schools. There are also private schools under state control. Students who completed the compulsory level successfully could proceed to secondary education where most of the schools are public. Private secondary schools make up only 8,2 percent of the secondary education system in Turkey (Eurydice (2010)). The duration of the secondary education is minimum four years. Some schools in which the medium of instruction is a foreign language in most of the courses, have a foreign language preparation grade. Thus, in these schools the secondary education lasts 5 years.

The public secondary education consists of two categories: general secondary education and vocational-technical secondary education. There are many different types of institutions in both categories 6 Vocational and technical education institutions aim not only prepare students for tertiary education but also to educate them as manpower for business and professional branches.

There are schools such as Anatolian high schools and science high schools that admit

\footnotetext{
${ }^{6}$ For further information on these institutions, see http://oogm.meb.gov.tr.
} 
students with entrance examination. Students are accepted to those schools according to secondary education placement score (Eurydice (2010)). This score is determined by the entrance exam and competence grades at the end of the 6th, 7th, and 8th class. The centralized nationwide entrance exam consists of multiple choice questions focusing on the curriculum. Year end competence grade is the mean of the two semesters' end averages of all courses.

\section{$3 \quad$ Data and Descriptive Statistics}

In the empirical analysis, we use the 2006 PISA survey which is a standardized achievement test in reading, mathematics and science among 15-year-olds enrolled in grades 7 or above 7 The implementation of PISA is coordinated by the Organization for Economic Cooperation and Development (OECD) at three-year intervals. The first PISA survey took place in 2000. Every period of assessment focuses on one particular subject. In the 2006 PISA, the focus is on science. Thus, the survey consists of questions that assess students' general and personal value of science, their interest and enjoyment of science and their self-beliefs as science learners (OECD (2007)). In addition to test scores in these three subjects, the 2006 PISA data set provides information on student, family and institutional factors that could help to explain differences in performance.

PISA 2006 implemented a two-stage stratified sample design. The first stage sampling units comprised individual schools having 15-year-old students. In the second stage, 35 students were randomly drawn with equal probability within each school. Final student weights were constructed to account for the probabilities of selection for individual nonresponse, or for errors in estimating the size of the school or the number of 15-year-olds in the school at the time of sampling. In our analysis, we used the sample weights provided

\footnotetext{
${ }^{7}$ Turkey participated in PISA in 2003, 2006 and 2009. PISA 2006 started to provide a parents questionnaire which is an important resource for the socioeconomic backgrounds of students. However, this questionnaire was optional and therefore not carried out in all the participating countries. As Turkey did not take part in the parents questionnaire in 2009. Our analysis is based only on the 2006 PISA survey
} 
in the PISA data set 8

Figures 1 and 2 present the mean gender test score gaps in science and mathematics for all OECD countries. The figures indicate that the gender gaps in cognitive skills show a similar trend. In mathematics, boys tend to outperform girls in all the countries except for Iceland. Gender differences are more pronounced in mathematics than in science. Only in six OECD countries (the United Kingdom, Luxembourg, Denmark, the Netherlands, Mexico, and Switzerland), boys on average have significantly higher science achievement than girls and the opposite is true in two OECD countries (Turkey and Greece). In addition, across OECD countries Turkey has the largest average gender test score gap in science while it has one of the smallest gap in mathematics across OECD countries 9

PISA is performed on a representative sample of the national population of 15-yearolds enrolled in school. However, in Turkey, most of the 15-year-old students are not subject to compulsory school attendance and 40-45 percent of 15-year-old children are not in school (Blancy and Sasmaz (2011)). Therefore, when evaluating the PISA results, one should take into account the fact that the selection into enrollment may not be random. The majority of children who are not enrolled in school are more likely to have lower academic achievement levels than those enrolled in school.

In PISA 2006, there were thirteen test booklets, each of which contained a slightly different subset of items. As each student was administered different items, the classic test scores, such as the percent of correct answers a student gets on a test, are not accurate measures of student performance. Thus, PISA 2006 used item response theory (IRT) to summarize the performance of a sample of students in a subject area with a simple scale or series of scales 10 For each test and each student, PISA 2006 reported five plausible values to present students' achievement. We use the average of those five plausible mathematics (science) values as a measure of the student's mathematics (science) performance in PISA

\footnotetext{
${ }^{8}$ For detailed information on the technical characteristics of the 2006 PISA, see OECD (2009).

${ }^{9}$ In Turkey, girls, on average, outscore boys in science by 12 score points. In mathematics, however, boys outscore girls by 6 score points.

${ }^{10}$ For more information on item response theory scaling methodology, see OECD (2009)
} 
2006.

The variables used to analyze the gender test score gap can be classified into the following three categories.

\subsection{Student Characteristics}

We control for a student's grade as it may have something to do with students' cognitive development. In order to capture a student's attitudes regarding the importance of studying math, we use students' responses to the following question: 'In general, how important do you think it is for you to do well in mathematics?' A four-point scale with the response categories recoded as 'very important' $(=4)$; 'important' $(=3)$; 'little important' $(=2)$; and 'not important at all' $(=1)$ is used. The 2006 PISA data set contains information on attitudinal measures consisting of self-efficacy, self-concept, interest in science, enjoyment of science, instrumental motivation to learn science and career intentions (OECD (2009)). We use two indexes to measure students' general level of belief in their academic abilities in science. The index of self-concept measures how students felt about their academic abilities in science. Table 2 shows six questions in the 2006 PISA designed to measure how good students felt they were at science. To assess self-efficacy in science, students were asked about their level of confidence in tackling specific scientific tasks. The notion of self-efficacy differs from self-concept as it includes not only a student's confidence in their ability to do science but also a student's belief in their ability to overcome difficulties when attempting scientific tasks (Marshall, Caygill, and May (2008)). The list of tasks presented to students is given in Table 2. We create the index of beliefs in own abilities in science by simply adding up indexes of self-efficacy and self-concept. The higher the index is, the more confident a student is about her/his academic abilities in science. To control for students' interest, enjoyment, and motivation with respect to science, we utilize three indexes. The index of general interest in science is based on a series of questions designed to gauge their interest in learning about science topics. The 
list of topics is shown in Table 3. The index of enjoyment of science measures how much students enjoy learning science topics and acquiring new knowledge in science. Students were asked questions about the usefulness of science for them and their future careers. The index of importance of learning science for future career is created by using students' responses to those questions that are listed in Table 3. The index of motivation in science is the simple sum of these three indexes. The higher the index is, the more motivated a student is to do well in science. In PISA 2006 students were also asked whether they think that they will have a science-related career when they are about 30 years old. We create an indicator variable that takes the value of one if the student expected to have a science-related career at age 30 and zero otherwise. We expect that students expecting to pursue a science-related career have higher science/math achievement than those who are not.

\subsection{Family Background Characteristics}

The 2006 PISA provides researchers with a number of variables that summarize socioeconomic status of family. We use parents' educational attainment, occupational status and family income as measures of family socioeconomic status. Parental education is measured by the highest level completed and classified into 3 categories: i) at most primary education; ii) secondary education; and iii) tertiary education. We utilize the index of the highest parental occupational status which is based on the International Socio-Economic Index of Occupational Status (ISEI). The value of the index ranges from 16 to 90. The higher values of the index are associated with occupations that have higher returns to education 11 We also include two binary variables indicating whether mother/father has a science-related career.

We use the number of books at home as an indicator of cultural capital. We create four dummy variables based on the following categories: i) 0 to 10 books; ii) 11 to 25 books; iii) 26 to 100 books; and iv) more than 100 books. We also control for the index of

\footnotetext{
${ }^{11}$ For detailed information on the construction of ISEI index, see Gazeboom et al. (1992)
} 
home education resources. This index is derived from the availability of various household items at home such as a study room, technical reference books, a computer that students can use for schoolwork and educational software 12

\subsection{School Characteristics}

We create an indicator variable taking the value of one if the school is in a rural area which is defined as a geographical unit with less than 15.000 inhabitants. We also create the following seven regional dummies as a set of controls for school location: Marmara region, Central Anatolian region, Aegean region, Mediterranean region, Blacksea region, Eastern Anatolian region and Southeastern Anatolian region. We divide schools into three types, namely general high schools, Anatolian high schools, and vocational high schools.13 To control for possible differences between public and private schools, we construct a variable indicating whether the school is public or private. Examining the effects and mechanisms of gender peer effects in elementary, middle, and high schools, Lavy and Schlosser (2011) find that an increase in the proportion of girls is associated with improvement in boys and girls' cognitive outcomes. To capture the potential favorable interaction between genders, we use sex ratio in the school that measures the proportion of girls enrolled at school. The variables that account for school resources are average class size, and the index of the quality of the school's educational resources. The computation of the index is based on the school principal's perceptions on potential factors hindering instruction at school. For example, the school principals were asked whether their schools' capacity to provide instruction is hindered by shortage of science laboratory equipment or computers

\footnotetext{
${ }^{12}$ See PISA 2006 Technical Report (OECD (2009), p. 316) for the construction of the index

${ }^{13}$ Schools are categorized into the following eight groups in the data set: primary schools, general high schools, Anatolian high schools, high schools with intensive foreign language teaching, science high schools, vocational high schools, Anatolian vocational high schools, secondary and vocational high Schools (also called multi-program high schools). It is important to note that when we construct school type indicator variables, we group Anatolian vocational high schools and high schools with intensive foreign language teaching as Anatolian high schools. As there is only one science high school in the data set, it is treated as an Anatolian high school. Moreover, secondary and vocational high schools are classified as vocational high schools. Primary schools are classified as general high schools.
} 
for instruction 14

\subsection{Descriptive Statistics}

Table 1 shows summary statistics for the final sample by gender. The final sample excludes cases with missing values on the variables. In mathematics, males have significantly higher average achievement than females. There is also a gender difference in perceived importance of doing well in Mathematics. Interestingly, females, on average, attribute more importance to mathematics. The mean test scores in science indicate a significant gender gap in favor of girls. However, there is no significant gender difference on the index of motivation in science. On average, girls have higher levels of belief in their scientific abilities than boys, but the difference is not statistically significant. $27 \%$ of females expect to have a science-related career at age 30 , compared to $25 \%$ of males. $94 \%$ of the students are enrolled in the $9^{\text {th }}$ grade or above. Students in the $7^{\text {th }}$ or the $8^{\text {th }}$ grades who did not complete their compulsory education make up only $4 \%$ of the sample 15

The descriptive statistics on family background characteristics indicates that the educational attainment of fathers is higher than that of mothers. For example, mothers with tertiary education make up $6 \%$ of the sample while $14 \%$ of fathers have tertiary education. Fathers with no secondary education constitute $55 \%$ of the sample whereas this rate is $72 \%$ for mothers. The distribution of the educational attainment of parents does not differ considerably between male and female samples. However, there is a significant difference between the average scores of males and females on the index of the highest parental occupational status. $5 \%$ of fathers and $2 \%$ of mothers have a science-related career. The average annual family income does not vary significantly between male and female samples. $91 \%$ of students are from families whose annual income is less than the median annual income (24.000 TL) in Turkey. The index of home education resources

\footnotetext{
${ }^{14}$ See PISA 2006 Technical Report (OECD (2009), p. 340) for detailed information on the construction of the index.

${ }^{15}$ In Turkey, the compulsory education ends after eighth grade. Therefore, our sample largely consists of students who are not subject to compulsory school attendance.
} 
does not show a significant gender difference whereas females seem to have more books at home than males.

$98 \%$ of students attend public schools. Almost half of the sample has a classroom size of at least 30 students. On average, females attend schools with a more balanced sex ratio than males do. Females are overrepresented among students who are enrolled in general high school and Anatolian high school and underrepresented among those who are enrolled in vocational high school.

The mean value of the index of the quality of the school's educational resources is -0.81 . The negative value provides evidence that instruction in schools, on average is hindered by a lack of adequate educational resources. The index does not differ significantly between male and female samples 16

One drawback of the PISA assessments is that they are based on the performance of 15-year-olds that are enrolled in formal education. Therefore, differential drop-out rates across genders may considerably influence the results. In the specific case of Turkey, there are significant gender differences in enrollment across regions. Akkoyunlu-Wigley and Wigley (2008) point out that females residing in rural areas and eastern provinces are less likely to attend school than their male counterparts 17 Consistent with the evidence provided in the literature, in our sample females are underrepresented among schools that are in rural areas and among those that are in Southeastern Anatolian and Blacksea regions. Given lower female enrollment rate, the sample of girls is likely to be positively selected sample of 15-year-old girls, which causes any gender gap favorable to boys to understate. One should take into account the possible selection bias when interpreting the results.

\footnotetext{
${ }^{16}$ It is important to note that the construction of the index relies on the judgment of school principals rather than on external observations or the views of students and teachers. Principals may not provide objective measures of the condition of physical infrastructure.

${ }^{17}$ Table IV in Akkoyunlu-Wigley and Wigley (2008) shows that in Turkey, the gender gap in secondary education enrollment is $6.1 \%$ in 2003 , ranging from $13.3 \%$ in Southeastern Anatolian region to $0.4 \%$ in Marmara region.
} 


\section{Econometric Model}

As an alternative to the standard OB decomposition 18 , we apply propensity score matching method to decompose the gender test score gap into the composition effect and the return effect. This method estimates the counterfactual outcomes for each individual separately, allowing us to account for heterogeneity across individuals (Heckman, LaLonde, and Smith (1999), Imbens (2004)). Moreover, the counterfactual outcomes are computed only over the common support. Decomposing the gender wage gap among college graduates in the UK, Frölich (2007) is the first to use such a matching procedure outside the treatment evaluation literature. Botezat and Seiberlich (2011) extend this procedure to estimate the threefold Oaxaca-Blinder decomposition semiparametrically and analyze the PISA test score gap between several Eastern European countries and Finland.

\footnotetext{
${ }^{18}$ In the standard $\mathrm{OB}$ decomposition the test score production function is assumed to be linear for both genders, i.e. $Y_{F}=X \beta_{F}+\varepsilon_{F}$ for females and $Y_{M}=X \beta_{M}+\varepsilon_{M}$ for males. Under the zero conditional mean assumption $\mathrm{E}\left[\varepsilon_{F} \mid X\right]=\mathrm{E}\left[\varepsilon_{M} \mid X\right]=0$. Let $\mathrm{D}$ is an dummy variable indicating whether the student is female. After taking the expectations over $\mathrm{X}$, the overall mean gender test score gap $\Delta$ can be written as follows:

$$
\begin{aligned}
\Delta & =\mathrm{E}\left[Y_{F} \mid D=1\right]-\mathrm{E}\left[Y_{M} \mid D=0\right] \\
& =\left(\mathrm{E}[X \mid D=1] \beta_{F}+\mathrm{E}\left[\varepsilon_{F} \mid D=1\right]\right)-\left(\mathrm{E}[X \mid D=0] \beta_{M}+\mathrm{E}\left[\varepsilon_{M} \mid D=0\right]\right)
\end{aligned}
$$
}

where $\mathrm{E}\left[\varepsilon_{F} \mid D=1\right]=\mathrm{E}\left[\varepsilon_{M} \mid D=0\right]=0$. After adding and subtracting the counterfactual test score for females, $\mathrm{E}[X \mid D=1] \beta_{M}$, which asks what would girls' test score be if they had the same returns to educational inputs as boys, the gender test score gap becomes:

$$
\Delta=(\mathrm{E}[X \mid D=1]-\mathrm{E}[X \mid D=0]) \beta_{M}+\mathrm{E}[X \mid D=1]\left(\beta_{F}-\beta_{M}\right)
$$

where the first term is called the composition effect which can be attributed to differences in average characteristics between females and males. The second term is due to differences in average returns to those characteristics and called the return effect.

The estimated gender test score gap is obtained by replacing the expected values of the covariates by the sample averages and the coefficients by their OLS estimates.

The detailed decomposition can be written as follows:

$$
\hat{\Delta}=\underbrace{\left(\bar{X}_{F}-\bar{X}_{M}\right) \hat{\beta}_{M}}_{\hat{\Delta}_{c}}+\underbrace{\bar{X}_{F}\left(\hat{\beta}_{F}-\hat{\beta}_{M}\right)}_{\hat{\Delta}_{r}}=\underbrace{\sum_{k=1}^{K}\left(\bar{X}_{F k}-\bar{X}_{M k}\right) \hat{\beta}_{M k}}_{\hat{\Delta}_{c}}+\underbrace{\left(\hat{\beta}_{F 0}-\hat{\beta}_{M 0}\right)+\sum_{k=1}^{K} \bar{X}_{F k}\left(\hat{\beta}_{F k}-\hat{\beta}_{M k}\right)}_{\hat{\Delta}_{r}}
$$

where $K$ is the number of regressors without constant, $\hat{\beta}_{F}$ is the vector of coefficients for females while $\hat{\beta}_{F k}$ is the coefficient of explanatory variable $k$ for females. The same distinction applies between $\hat{\beta}_{M}$ and $\hat{\beta}_{M k}$ for males. $\bar{X}_{F}=\frac{1}{n_{F}} \sum_{i \in F} X_{i}, \bar{X}_{M}=\frac{1}{n_{M}} \sum_{i \in M} X_{i}, \bar{X}_{F k}=\frac{1}{n_{F}} \sum_{i \in F} X_{i k}$ and $\bar{X}_{M k}=\frac{1}{n_{M}} \sum_{i \in M} X_{i k}, n_{F}$ is the number of females and $n_{M}$ the number of males in the samples. 
To obtain the propensity score, we estimate the probability that an individual is female $(D=1)$ by a logit regression, i.e. $p=\operatorname{Pr}[D=1 \mid X=x]=F\left(x^{\prime} \beta\right)$, where $F\left(x^{\prime} \beta\right)$ represents the cumulative logistic distribution. Next, we estimate the density of this propensity score using a Kernel estimator. Let $f_{1}(p), f_{0}(p)$ be the distributions of the propensity score $P=P(X)$ for females $(D=1)$ and males $(D=0)$ respectively. $f_{1}^{S}(p)$ and $f_{0}^{S}(p)$ denote the corresponding densities for the common support subpopulation $S, 19$

Figure 3 presents the densities of the estimated propensity scores for females and males. We define the common support as $\left\{S: \hat{p}_{i} \in\left[\hat{p}^{\min _{M}}, \hat{p}^{\max _{M}}\right]\right\}$, i.e. all observations with an estimated propensity score that is smaller than the maximum propensity score of males $\left(\hat{p}^{\max _{M}}\right)$ and larger than the minimum estimated propensity score of males $\left(\hat{p}^{\min _{M}}\right)$ belong to the common support subpopulation.

For the common support subpopulation, the gender test score gap can be written as follows:

$$
\begin{aligned}
\Delta_{S} & =E_{S}\left[Y^{1} \mid D=1\right]-E_{S}\left[Y^{0} \mid D=0\right] \\
& =\int_{S} E[Y \mid P(X)=p, D=1] f_{1}^{S}(p) \mathrm{dp}-\int_{S} E[Y \mid P(X)=p, D=0] f_{0}^{S}(p) .
\end{aligned}
$$

where $Y^{0}$ and $Y^{1}$ denote the potential outcomes.

Frölich (2007) shows that the counterfactual outcome is identified as follows:

$$
E_{S}\left[Y^{0} \mid D=1\right]=\int_{S} E[Y \mid P(X)=p, D=0] f_{1}^{S}(p) \mathrm{dp}
$$

The counterfactual represents the expected test score that females $(D=1)$ would have if they had the same returns to educational inputs as males $(D=0)$.

We estimate the expected outcome for $P(X)=p$ by the ridge regression proposed by Seifert and Gasser (1996). This estimator is a convex combination of the local constant

\footnotetext{
$19 f_{d}^{S}(p)=\frac{f_{d}(p)}{\mu_{S \mid D=d}}$ is scaled such that the integral integrates to one, where $\mu_{S \mid D=d}$ is the empirical probability of being on the common support conditional on having gender $d$.
} 
and local linear estimators. Several Monte Carlo studies show that this estimator has a better performance than other matching estimators (see Frölich (2004), Busso, DiNardo, and McCrary (2011)). The ridge regression takes the following form:

$$
\hat{E}[Y \mid P(X)=p, D=0]=(1-\bar{R}) \frac{T_{0}}{S_{0}}+\bar{R}\left(\frac{T_{0}}{S_{0}}+\frac{T_{1}(p-\bar{p})}{S_{2}}\right)
$$

where $\bar{R}=\frac{S_{2}}{S_{2}+R}, \quad \bar{p}=\sum_{i}^{n_{0}} \frac{K\left(\frac{p_{i}^{0}-p}{h}\right) p_{i}^{0}}{K\left(\frac{p_{i}^{0}-p}{h}\right)}, \quad S_{j}=\sum_{i}^{n_{0}} K\left(\frac{p_{i}^{0}-p}{h}\right)\left(p_{i}^{0}-\bar{p}\right)^{j}$ and $T_{j}=\sum_{i}^{n_{0}} K\left(\frac{p_{i}^{0}-p}{h}\right)\left(p_{i}^{0}-\bar{p}\right)^{j} Y_{i}^{0}$. Thereby $K$ is the kernel function, $h$ the bandwidth, $n_{0}$ the number of observations and $p^{0}$ the propensity score of those from group $0 . \bar{p}$ is chosen such that $S_{1}=0$ and $R$ is the ridge parameter. Seifert and Gasser (2000) develop a rule of thumb for choosing $R$, according to their rule of thumb the ridge parameter for local linear regressions is $R=r h|p-\bar{p}|$. Thus, this ridge parameter depends on the point of evaluation $p$ the bandwidth $h$ and $r=\frac{\max _{u}(K(u))}{4 \int K^{2}(u) d u}$, e.g. as we use a Gaussian Kernel, $r=0.3535$.

The bandwidths are selected by leave-one-out cross-validation and are chosen to minimize the least-squares criterion: $h^{*}=\arg \min _{h \in H} \sum_{j \in I_{0}}\left(Y_{j}-\hat{E}_{-j}\left[Y_{j} \mid D_{j}=0, P_{j}(X)=\right.\right.$ $\left.\left.p_{j}\right]\right)^{2}$, where $\hat{E}_{-j}\left[Y_{j} \mid D_{j}=0, P_{j}(X)=p_{j}\right]$ is the out of sample predicted outcome for observation $j$ that is obtained from the data sample without observation $j$. Following Frölich (2004) we choose as bandwidth search grid $0.01 \sqrt{1.2}^{g-2}$ for $g=1, \ldots, 59$ and $\infty$.

After adding and subtracting the counterfactual outcome in (2), we can decompose the gender test score gap for the common support subpopulation in (1), into two parts:

$$
\begin{aligned}
\Delta_{S} & =\underbrace{\int_{S} E[Y \mid P(X)=p, D=0]\left[f_{1}^{S}(p)-f_{0}^{S}(p)\right] \mathrm{dp}}_{\Delta_{c}} \\
& +\underbrace{\int_{S}[E[Y \mid P(X)=p, D=1]-E[Y \mid P(X)=p, D=0]] f_{1}^{S}(p) \mathrm{dp}}_{\Delta_{r}}
\end{aligned}
$$


The first term can be attributed to differences in the distribution of propensity scores between females and males and is called the composition effect $\left(\Delta_{c}\right)$. It would vanish if females had the same characteristics as males. The second term is due to differences in returns to these characteristics and thus called the return effect $\left(\Delta_{r}\right)$. It would vanish if females had the same returns to educational inputs as males.

The identification of the composition and return effects crucially relies on two assumptions. The first one is the conditional independence assumption (CIA) which guarantees that conditional on confounding variables the potential outcomes are stochastically independent of the treatment: $Y_{i}^{0} \perp D_{i} \mid P_{i}(X)$, where $P_{i}(X)$ denotes the propensity score based on the confounding variables of individual $i$. The CIA requires that all confounding factors associated with the potential outcomes as well as the treatment status are observed.

To justify the CIA, we control for a rich set of covariates available in the PISA data set, including student, family background, and school characteristics. Although we do not have information on innate ability, the data set allows us to construct two indexes that provide subjective measures of ability and motivation in science. Those indexes at least partially account for potentially endogenous effects. Moreover, Fortin, Lemieux, and Firpo (2011) point out that the aggregate decomposition would even be valid in the presence of the correlation between unobserved and observed characteristics under the condition that the correlation is the same for both genders.

The second assumption is the overlap assumption. It requires that the probability of being female is smaller than one, i.e. $\operatorname{Pr}(D=1 \mid X)<1$. This type of overlap assumption is standard in the literature (e.g. Rosenbaum and Rubin (1983), Heckman, Ichimura, and Todd (1997), Hahn (1998), Wooldridge (2002), Imbens (2004))20 To guarantee that

\footnotetext{
${ }^{20}$ There is a stronger version of the overlap assumption called strict overlap (e.g Robins, Rotnitzky, and Zhao (1994), Abadie and Imbens (2006), Crump, Hotz, Imbens, and Mitnik (2009)). Strict overlap requires that the probability of being female is strictly smaller than $1-\xi$ for some $\xi>0$. Khan and Tamer (2010) point out that something similar to the strict overlap assumption is needed for $\sqrt{N}$ - convergence of some semiparametric estimators. Busso, DiNardo, and McCrary (2011) provide further evidence on the importance of (strict) overlap assumption.
} 
$\operatorname{supp}(X \mid D=1) \subseteq \operatorname{supp}(X \mid D=0)$ we restrict the estimation of the composition and return effect to the common support subpopulation.

To account for the observations in the sample that cannot be matched, we follow Nopo (2008) and decompose the whole gap $\Delta$ into three parts: $\Delta=\Delta_{1}+\Delta_{c}+\Delta_{r} 21$ In addition to the composition and return effects, we have $\Delta_{1}$ which represents the part of the test score gap that can be explained by differences between two groups of females: those who can be matched with males and those who remain out of the common support, weighted by the empirical fraction of females who are out of the common support. A positive value of $\Delta_{1}$ indicates that female students, who are out of the common support, perform better than their counterparts, who are in the common support.

This semiparametric approach also allows us to decompose the gender test score gap for the common support subpopulation into the the composition and return effects at different quantiles. The two parts of the gap at quantile $\tau$ can be estimated as follows:

$$
\begin{aligned}
& \Delta_{r}^{\tau}=F_{y^{1} \mid D=1, S}^{-1}(\tau)-F_{y^{0} \mid D=1, S}^{-1}(\tau) \\
& \Delta_{c}^{\tau}=F_{y^{0} \mid D=1, S}^{-1}(\tau)-F_{y^{0} \mid D=0, S}^{-1}(\tau) \\
& \Delta_{S}^{\tau}=\Delta_{r}^{\tau}+\Delta_{c}^{\tau}=F_{y^{1} \mid D=1, S}^{-1}(\tau)-F_{y^{0} \mid D=0, S}^{-1}(\tau)
\end{aligned}
$$

${ }^{21}$ The gap can be written explicitly as follows:

$$
\begin{aligned}
\Delta & =\underbrace{\mu_{\bar{S} \mid D=1}\left[\int_{\bar{S}} E[Y \mid P(X)=p, D=1] f_{1}^{\bar{S}}(p) \mathrm{dp}-\int_{S} E[Y \mid P(X)=p, D=1] f_{1}^{S}(p) \mathrm{dp}\right]}_{\Delta_{1}} \\
& \left.+\int_{S} E[Y \mid P(X)=p, D=1] f_{1}^{S}(p) \mathrm{dp}-\int_{S} E[Y \mid P(X)=p, D=0] f_{0}^{S}(p) \mathrm{dp}\right] \\
& +\underbrace{\left[\mu_{\bar{S} \mid D=0}\left[\int_{S} E[Y \mid P(X)=p, D=0] f_{0}^{S}(p) \mathrm{dp}-\int_{\bar{S}} E[Y \mid P(X)=p, D=0] f_{0}^{\bar{S}}(p) \mathrm{dp}\right]\right.}_{\Delta_{0}}
\end{aligned}
$$

where $\bar{S}$ denotes out of the common support and $\mu_{\bar{S} \mid D=d}$ the empirical probability of being unmatched conditional on having gender $d$. As before, the second summand can be decomposed into $\Delta_{c}$ and $\Delta_{r}$. Due to our definition of the common support $\mu_{\bar{S} \mid D=0}=0$. 
The adjusted quantiles are obtained indirectly via inverting the adjusted distribution functions.

\section{Results}

\subsection{The Standard OB Decomposition}

\subsubsection{Gender Test Score Gap in Mathematics}

Table 4 presents OLS estimates of the gender test score gap in math. As one moves to right in the table, the number of covariates steadily increases. The raw gap is 8.6 score points in favor of males. Column 2 adds controls for student's characteristics. The coefficients of grade indicator variables are positive and statistically significant. Students in the $9^{\text {th }}$, $10^{\text {th }}$ and $11^{\text {th }}$ grades have significantly higher test scores compared to those who are in the $7^{\text {th }}$ or $8^{\text {th }}$ grade. The higher levels on the index of beliefs in own abilities in science is associated with higher achievement in mathematics. Students who expected to pursue a scientific career and placed a higher value on mathematics score significantly higher on the test. These results are robust across all specifications. The index of motivation in science has an unexpected negative sign in column 2. However, the coefficient of the index becomes statistically insignificant when we control for family background and school characteristics. The test score gap remains negative and significant when the controls for family background variables are included in column 3. Almost all these controls enter with the expected sign. The number of books is significantly positively associated with test score on math. Parents' education and occupational status and family income are important predictors of math test score. Students from families with higher socioeconomic status score better. The coefficient on the index of home educational resources is positive and statistically significant. Students with mothers who have a science-related career score better. However, it does not matter whether the father is in science-related occupation.

The final specification in Table 4 also adds a set of covariates capturing school char- 
acteristics. As expected, students who attend schools in an rural area and those with low quality of educational resources score worse. A more balanced sex ratio at school is associated with a higher math test score. Compared to students attending schools in Marmara region, those attending schools in Aegean, Mediterranean, and Blacksea regions score better while those attending in Eastern Anatolian and Southeastern regions score worse. School type matters. Students from Anatolian high school score better but, those from vocational high school perform worse than those from general high school. It is worth noting that in Table 4, the gender test score gap becomes larger than the raw gap when the number of covariates increases. The estimates suggest that controlling for other factors, females score worse than males in math.

Because females and males may not be equally responsive to changes to covariates, we perform the analysis separately for males and females. The results presented in columns 1 and 2 of Table 6 suggest that the responsiveness to motivation and ability indexes varies across genders. The effect of motivation index on math achievement is statistically significant only for males while the effect of the ability index is statistically significant only for females. Father's education is more important for daughters. Moreover, coefficients on school characteristics show important differences between males and females.

Table 7 presents the results from the standard OB decomposition for a reduced set of three factors: student characteristics, family characteristics and school characteristics. The composition effect is positive and statistically significant at the $1 \%$ level, implying that gender differences in observable characteristics predict an advantage for females over males in the average mathematics scores. School characteristics are by far the most important explanatory factors contributing to the composition effect. Students and family characteristics account for 11.3 percent and 8.7 percent of the composite effect respectively. The return effect is negative and statistically significant at the $1 \%$ level, suggesting that males are better able to convert educational inputs into higher math test scores. The contributions of student and family characteristics to the return effect are negative but statistically insignificant, indicating that there is no discernible gender difference in trans- 
forming student and family inputs into math test scores. The negative and statistically significant contribution of school characteristics to the return effect suggests that males appear to have a particular advantage with converting school inputs into better math test scores.

\subsubsection{Gender Test Score Gap in Science}

OLS estimates of the gender test score gap in science is presented in Table 5 . The raw test score gap in science is 10 score points in favor of females. As expected, students with a more positive view of their abilities in science and those expecting to pursue a science-related career at age 30 tend to have higher scores. The more motivated a student is to do well in science, the higher achievement in science. Moreover, students who attribute more importance to math score better. When we include family background characteristics, the gender test score gap decreases in magnitude but remains statistically significant. Parental education, income, and occupational status, whether mother has a science-related career, the number of books at home, and the index of home education resources are statistically significant in explaining scientific literacy achievement. The next specification in column 4 adds the school input measures. The gender test score gap diminishes further in magnitude and loses statistical significance when these variables are included. School location and type, proportion of girls enrolled at school, and average class size are statistically significant predictors of achievement in science.

The results presented in columns 3 and 4 of Table 6 suggest that variables associated with statistically significant estimated coefficients are nearly the same for both gender, implying that there is no substantial difference between male and female education production function. However, the responsiveness to different covariates changes across genders. For instance, as in the case of math test results, father's education is more important for daughters and males respond to school characteristics differently than females do.

The standard OB Decomposition results are presented in Table 8. The composition effect is positive and statistically significant, suggesting that gender differences in ob- 
servable characteristics predict an advantage for girls over boys in the science test score. Consistent with math test score results, school characteristics is the most important factor contributing to the composition effect. The contribution of family characteristics to the composition effect is not statistically significant while differences in student characteristics account for only 4.1 percent of the composition effect. The return effect is negative and statistically significant, providing evidence that males are more efficient in transforming educational inputs into higher science test scores. Similar to the decomposition results for math score presented in Table 7, the most important advantage for males results from higher returns to school inputs and the contributions of student and family characteristics to the return effect are negative but statistically insignificant.

\subsection{The Semiparametric OB Decomposition}

Table 9 presents the results from the semiparametric OB decomposition of the mean test score gap that restricts the comparison to the common support. The upper panel of Table 9 shows the results for science while the lower part shows those for mathematics. As one moves down in both lower and upper panels of the table, the set of covariates steadily grows. In the final specification, the percentage of females who are out of the common support is 12.5 percent 22

The following conclusions can be drawn from Table 9. In science, except the first specification which controls for only student characteristics, the composition effect is positive and statistically significant, implying that gender differences in observable characteristics predict an advantage for girls over boys. As expected, the composition effect increases as we control for more covariates in the model. The contribution of school characteristics to the composition effect is very important. The return effect becomes statistically insignificant when we control for school characteristics. The final specification presented

\footnotetext{
${ }^{22}$ In Table 9, the percentage of females who are out of the common support changes across specifications. In the first specification which only controls for student characteristics, 0.29 percent of females are out of the common support while this rate is 0.04 percent for the second specification which controls for student and family characteristics and 12.47 percent for the final specification which also adds school characteristics to the second specification.
} 
in the third row of Table 9 indicates that girls outperform boys in science by 15.2 points. In math, the mean test score gap is 8.7 points in favor of boys in the first two specifications, however it turns out to be statistically insignificant in the final specification. A comparison of the results presented in Table 9 and those in Tables 7 and 8 reveals that the standard $\mathrm{OB}$ decomposition tends to underestimate the component of the gender test score gap attributable to the composition effect.

Table 10 presents the results from the semiparametric OB decomposition that also accounts for the out-of-common-support observations. The mean test score gap in the science (math) in the full sample is 10.1 (-8.7) points and thus very different from the gap in the common support subpopulation presented in Table 9. This finding points to the importance of restricting the comparison only to those individuals with comparable characteristics. $\Delta_{r}$ and $\Delta_{c}$ are the same as those in Table 9 and they are computed only over the common support. $\Delta_{1}$, the difference between females who can be matched with males and those who cannot, is statistically significant only in the final specification which controls for student, family and school characteristics. In both science and math, the negative value of $\Delta_{1}$ indicates that females who are in the common support perform better than those who are out of the common support.

It is worth noting that the outperformance of girls over boys in science could be partially explained by the fact that there exist gender differences in secondary education enrollment rate in Turkey where boys have higher enrolment rates than girls. Therefore, our sample is likely to be composed of a positively selected sample of girls, causing the overestimation of the gender gap favorable to girls 23

Table 11 presents the results from the semiparametric OB decomposition at different quantiles, allowing us understand the heterogenous pattern across the distribution. The top panel of Table 11 shows that in science, the gap is in favor of girls and statistically significant until the top quantile. The largest gap takes place at the $50^{\text {th }}$ quantile. The

\footnotetext{
${ }^{23}$ Table 1 shows that most of the 15 -year-old students in our sample are not subject to compulsory education which ends after $8^{\text {th }}$ grade.
} 
bottom panel of Table 11 indicates that in math, the gap is is statistically significant only at the top of the distribution. At the top end, girls lag significantly behind boys. The composition effect is negative and statistically significant, suggesting that boys possess more of the characteristics associated with high math scores. Therefore, targeting resources to girls at the top of the distribution would be the efficient way to close the gap in math.

\section{Conclusion}

In this paper, we use a semiparametric Oaxaca-Blinder (OB) decomposition to investigate the gender PISA test score gap in mathematics/science in Turkey. Our semiparametric approach differs from the standard OB decomposition in several aspects. It decomposes the average test score gap for the common support population and relaxes the parametric assumptions of the standard OB decomposition. Moreover, it allows us to examine the gender test score gap at different quantiles of the test score distribution.

The results for the semiparametric OB decomposition evaluated at the mean of test scores indicate that the gender test score gap is 15.2 points in favor of girls in science while it is not statistically significant in math. The positive and statistically significant composition effect suggest that girls possess more of characteristics associated with high science test scores. School characteristics plays an important role in explaining the gap. Our findings provide evidence that the failure to recognize the common support problem leads to an underestimation of the composition effect. We also find that the gender test score gap changes across the test score distribution. In math, the gap is statistically significant only at the top end of the distribution suggesting that high-achieving boys perform better than high-achieving girls in math. In science, the gap favoring girls is statistically significant until the top quantile and the largest gap occurs at the $50^{\text {th }}$ quantile. 


\section{References}

Abadie, A., and G. W. Imbens (2006): "Large Sample Properties of Matching Estimators for Average Treatment Effects," Econometrica, 74(1), pp. 235-267.

Akkoyunlu-Wigley, A., and S. Wigley (2008): "Basic education and capability development in Turkey," Education in Turkey, Waxmann, Münster, pp. 271-97.

Ammermüller, A. (2007): "PISA: What makes the difference? Explaining the gap in test scores between Finland and Germany," Empirical Economics, 33(2), 263-287.

Aypay, A., M. ERdoĞAn, And M. SÖZER (2007): "Variation among schools on classroom practices in science based on TIMSS-1999 in Turkey," Journal of Research in Science Teaching, 44(10), 1417-1435.

Blancy, N. K., And A. Sasmaz (2011): "PISA 2009: Where Does Turkey Stand?," Turkish Policy Quarterly, 10(2).

Blinder, A. (1973): "Wage discrimination: reduced form and structural estimates," Journal of Human resources, pp. 436-455.

Botezat, A., And R. Seiberlich (2011): "How Far is the East? Educational Performance in Eastern Europe," University of Konstanz Economics Working Paper No. 2011-15.

Brosnan, M. (2006): "Digit ratio and faculty membership: Implications for the relationship between prenatal testosterone and academia," British journal of psychology, $97(4), 455-466$.

Busso, M., J. DiNARdo, And J. MCCRARY (2011): "Finite sample properties of semiparametric estimators of average treatment effects," Journal of Business and Economic Statistics, forthcoming. 
Cahill, L. (2012): "His brain, her brain," Special Editions, Scientific American, 1(1), $46-53$.

Carneiro, P., And J. Heckman (2003): Human capital policy. National Bureau of Economic Research.

Carrell, S., M. Page, and J. West (2009): "Sex and science: How professor gender perpetuates the gender gap," The Quarterly Journal of Economics, 125(3), 1101-1144.

CAygill, R. (2008): PISA 2006: Student attitudes to and engagement with science - how ready are our 15-year-olds for tomorrow's world? Wellington: Ministry of Education.

Ceci, S., W. Williams, and S. Barnett (2009): "Women's underrepresentation in science: Sociocultural and biological considerations.," Psychological Bulletin, 135(2), $218-261$.

Crump, R. K., V. J. Hotz, G. W. Imbens, and O. A. Mitnik (2009): "Dealing with Limited Overlap in Estimation of Average Treatment Effects," Biometrika, 96, $1987-199$.

Davison, K., And E. Susman (2001): "Are hormone levels and cognitive ability related during early adolescence?," International Journal of Behavioral Development, 25(5), $416-428$.

DayioĞLu, M., M. Kirdar, and A. Tansel (2009): "Impact of Sibship Size, Birth Order and Sex Composition on School Enrolment in Urban Turkey," Oxford Bulletin of Economics and Statistics, 71(3), 399-426.

DAYioĞLu, M., And S. TÜRÜT-AşıK (2007): "Gender differences in academic performance in a large public university in Turkey," Higher Education, 53(2), 255-277.

Dincer, M., And G. Uysal (2010): "The determinants of student achievement in Turkey," International Journal of Educational Development, 30(6), 592-598. 
Duncan, K. C., And J. SAndy (2007): "Explaining the Performance Gap Between Public and Private School Students," Eastern Economic Journal, 33(2), 177-191.

Erberber, E. (2009): "Analyzing Turkey," ProQuest LLC, p. 199.

EuRYDICE (2010): "Organisation of the education system in Turkey," .

Fortin, N., T. Lemieux, And S. Firpo (2011): "Decomposition methods in economics," Handbook of Labor Economics, 4, 1-102.

FrÖLICH, M. (2007): "Propensity score matching without conditional independence assumption-with an application to the gender wage gap in the United Kingdom," Econometrics Journal, 10(2), 359-407.

FrÖLICH, M. (2004): "Finite-sample properties of propensity-score matching and weighting estimators," Review of Economics and Statistics, 86(1), 77-90.

Fryer, R., And S. LevitT (2010): “An empirical analysis of the gender gap in mathematics," American Economic Journal: Applied Economics, 2(2), 210-240.

Fuchs, T., And L. Woessmann (2007): "What accounts for international differences in student performance? A re-examination using PISA data," Empirical Economics, $32(2), 433-464$.

Guiso, L., F. Monte, P. Sapienza, And L. Zingales (2008): "Culture, gender, and math," Science-New York then Washington-, 320(5880), 1164.

Hahn, J. (1998): "On the Role of the Propensity Score in Efficient Semiparametric Estimation of Average Treatment Effects," Econometrica, 66(2), pp. 315-331.

HanusheK, E. (2008): Schooling, Gender Equality, and Economic OutcomeGirls' Education in the 21st Century: Gender Equality, Empowerment, and Economic Growth, The International Bank for Reconstruction and Developement/The World Bank. 
HanusheK, E., And D. Kimko (2000): "Schooling, labor-force quality, and the growth of nations," American economic review, pp. 1184-1208.

HANusheK, E., AND J. Luque (2003): "Efficiency and equity in schools around the world," Economics of education Review, 22(5), 481-502.

Hanushek, E.A., V. L., And K. Hitomi (2008): "Do Students Care about School Quality? Determinants of Dropout Behavior in Developing Countries," Journal of Human Capital, pp. 69-105.

Heckman, J., H. Ichimura, and P. Todd (1997): "Matching as an econometric evaluation estimator: Evidence from evaluating a job training programme," The Review of Economic Studies, 64(4), 605-654.

Heckman, J. J., R. LaLonde, and J. Smith (1999): The Economics and Econometrics of Active Labor Market Programs, Handbook of Labour Economics, Vol. 3, 1865-2097, O. Ashenfelter and D. Card (eds.), Amsterdam: North-Holland.

Hille, A. (2011): "The gender gap in mathematics in French primary school," Master's thesis.

Hisarciklilar, M., A. MCKay, and P. Wright (2010): "Gender Based Differences in Educational Achievement in Turkey: What Has Changed Over Time?," Working Paper, presented at the 30th Annual Conference of the MEEA.

Imbens, G. (2004): "Nonparametric Estimation of Average Treatment Effects Under Exogeneity," Review of Economics and Statistics, 86, 4-29.

JACOBS, J., AND J. ECCLES (1992): "The impact of mothers' gender-role stereotypic beliefs on mothers' and children's ability perceptions.," Journal of Personality and Social Psychology, 63(6), 932. 
Jamison, E., D. Jamison, And E. Hanushek (2007): "The effects of education quality on mortality decline and income growth," Economics of Education Review, 26(6), 772789.

Khan, S., and E. TAmer (2010): "Irregular Identification, Support Conditions, and Inverse Weight Estimation," Econometrica, 78, 2021-2042.

Krieg, J., And P. Storer (2006): "How much do students matter? Applying the Oaxaca decomposition to explain determinants of adequate yearly progress," Contemporary Economic Policy, 24(4), 563-581.

Kucian, K., T. Loenneker, T. Dietrich, E. Martin, and M. Von Aster (2005): "Gender differences in brain activation patterns during mental rotation and number related cognitive tasks," Psychology Science, 47(1), 112-131.

Lara-Cinisomo, S., A. Pebley, M. Vaiana, E. Maggio, M. Berends, and S. LuCAS (2004): "A matter of class," Rand review, 28(3), 10-5.

Lavy, V., And A. Schlosser (2011): "Mechanisms and Impacts of Gender Peer Effects at School," American Economic Journal: Applied Economics, 3(2), 1-33.

Marshall, N., R. Caygill, and S. May (2008): PISA2006: Reading Literacy: How Ready are Our 15-year-olds for Tomorrow's World? Comparative Education Research Unit, Research Division, Ministry of Education.

MCEwan, P. J. (2004): "The Indigenous Test Score Gap in Bolivia and Chile," Economic Development and Cultural Change, 53(1), 157-90.

Mulligan, C. (1999): "Galton versus the human capital approach to inheritance," Journal of Political Economy, 107(S6), 184-224.

Murnane, R., J. Willett, Y. Duhaldeborde, and J. Tyler (2000): "How important are the cognitive skills of teenagers in predicting subsequent earnings?," Journal of Policy Analysis and Management, 19(4), 547-568. 
Nonoyama-TARumi, Y., And J. Willms (2010): "The relative and absolute risks of disadvantaged family background and low levels of school resources on student literacy," Economics of Education Review, 29(2), 214-224.

Nopo, H. (2008): "Matching as a Tool to Decompose Wage Gaps," Review of Economics and Statistics, 90(2), 290-299.

OAXACA, R. (1973): "Male-female wage differentials in urban labor markets," International economic review, 14(3), 693-709.

OECD (2007): Education at a Glance 200\%. Organisation for Economic Co-operation and Development and Programme for International Student Assessment, Paris.

(2009): PISA 2006 Technical Report. Organisation for Economic Co-operation and Development and Programme for International Student Assessment, Paris.

— (2010): PISA 2009 Results: What Students Know and Can Do. Student Performance in Reading, Mathematics and Science. Organisation for Economic Co-operation and Development and Programme for International Student Assessment, Paris.

Pope, D., And J. Sydnor (2010): "Geographic variation in the gender differences in test scores," The Journal of Economic Perspectives, 24(2), 95-108.

Robins, J. M., A. Rotnitzky, and L. P. Zhao (1994): "Estimation of Regression Coefficients when Some Regressors are not Always Observed," Journal of the American Statistical Association, 89, 846-866.

Rosenbaum, P. R., And D. B. Rubin (1983): "The central role of the propensity score in observational studies for causal effects," Biometrika, 70(1), 41-55.

Sakellariou, C. (2008): "Peer effects and the indigenous/non-indigenous early testscore gap in Peru," Education Economics, 16(4), 371-390. 
Seifert, B., And T. Gasser (1996): "Finite-sample variance of local polynomials: analysis and solutions," Journal of the American Statistical Association, pp. 267-275.

— (2000): "Data adaptive ridging in local polynomial regression," Journal of Computational and Graphical Statistics, pp. 338-360.

Smits, J., And A. Hosgor (2006): "Effects of family background characteristics on educational participation in Turkey," International Journal of Educational Development, $26(5), 545-560$.

Sohn, K. (2010): "A new insight into the gender gap in math," Bulletin of Economic Research.

TANsel, A. (2002): "Determinants of school attainment of boys and girls in Turkey: individual, household and community factors," Economics of Education Review, 21(5), $455-470$.

Tiedemann, J. (2000): "Parents' gender stereotypes and teachers' beliefs as predictors of children's concept of their mathematical ability in elementary school.," Journal of Educational Psychology, 92(1), 144.

Wooldridge, J. M. (2002): Econometric Analysis of Cross Section and Panel Data. MIT Press, Cambridge, MA.

Wössmann, L. (2003): "Schooling resources, educational institutions and student performance: the international evidence," Oxford Bulletin of Economics and Statistics, 65(2), $117-170$.

(2009): School Accountability, Autonomy and Choice around the WorldElgar, Cheltenham. 
Table 1: Descriptive Statistics by Gender

\begin{tabular}{|c|c|c|c|c|c|c|c|c|}
\hline \multirow[b]{2}{*}{ Variable } & \multirow[b]{2}{*}{ Description } & \multicolumn{2}{|c|}{ Full Sample } & \multicolumn{2}{|c|}{ Male } & \multicolumn{2}{|c|}{ Female } & \multirow[b]{2}{*}{ t-Test } \\
\hline & & Mean & St. Dv. & Mean & St. Dv. & Mean & St. D. & \\
\hline \multicolumn{9}{|l|}{ Test Scores } \\
\hline 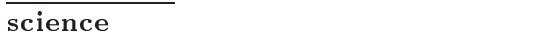 & science test score & 432.05 & 78.42 & 427.41 & 80.19 & 437.51 & 75.94 & -4.00 \\
\hline math & math test score & 432.35 & 87.68 & 436.33 & 90.43 & 427.66 & 84.11 & 3.07 \\
\hline \multicolumn{9}{|l|}{ Student Characteristics } \\
\hline $8^{\text {th }}$ grade & $=1$ if the student is in $7^{\text {th }}$ or $8^{\text {th }}$ grade & 0.04 & 0.19 & 0.04 & 0.20 & 0.03 & 0.18 & 1.28 \\
\hline $9^{\text {th }}$ grade & $=1$ if the student is in $9^{\text {th }}$ grade & 0.40 & 0.49 & 0.39 & 0.49 & 0.40 & 0.49 & -0.49 \\
\hline $10^{\text {th }}$ grade & $=1$ if the student is in $10^{\text {th }}$ grade & 0.54 & 0.50 & 0.53 & 0.50 & 0.54 & 0.50 & -0.42 \\
\hline $11^{\text {th }}$ grade & $=1$ if the student is in $11^{\text {th }}$ grade & 0.03 & 0.16 & 0.03 & 0.17 & 0.02 & 0.15 & 1.28 \\
\hline science career & $\begin{array}{l}=1 \text { if the student is expected } \\
\text { to have a science-related career at } 30\end{array}$ & 0.26 & 0.44 & 0.25 & 0.43 & 0.27 & 0.44 & -1.66 \\
\hline motivation index & index of motivation in science & 1.07 & 2.45 & 1.01 & 2.43 & 1.13 & 2.47 & -1.54 \\
\hline ability index & index of belief in own ability in science & 0.21 & 1.66 & 0.20 & 1.73 & 0.22 & 1.58 & -0.42 \\
\hline math is important & $\begin{array}{c}\text { How important is math, } 4=\text { 'very important' } \\
1=\text { 'not important at all' }\end{array}$ & 3.62 & 0.66 & 3.58 & 0.69 & 3.67 & 0.62 & -4.34 \\
\hline \multicolumn{9}{|l|}{ Family Background Characteristics } \\
\hline mother-primaryeduc & $=1$ if the mother has at most primary education & 0.72 & 0.45 & 0.72 & 0.45 & 0.71 & 0.45 & 0.91 \\
\hline mother-secondaryeduc & $=1$ if the mother has secondary education & 0.22 & 0.42 & 0.21 & 0.41 & 0.23 & 0.42 & -1.81 \\
\hline mother-tertiaryeduc & $=1$ if the mother has tertiary education & 0.06 & 0.24 & 0.07 & 0.25 & 0.06 & 0.23 & 1.42 \\
\hline father-primaryeduc & $=1$ if the father has at most primary education & 0.55 & 0.50 & 0.55 & 0.50 & 0.54 & 0.50 & 0.91 \\
\hline father-secondaryeduc & $=1$ if the father has secondary education & 0.31 & 0.46 & 0.30 & 0.46 & 0.32 & 0.47 & -1.80 \\
\hline father-tertiaryeduc & $=1$ if the father has tertiary education & 0.14 & 0.35 & 0.15 & 0.36 & 0.14 & 0.34 & 1.08 \\
\hline books $\leq \mathbf{1 0}$ & $=1$ if the number of books at home $\leq 10$ & 0.23 & 0.42 & 0.27 & 0.44 & 0.18 & 0.39 & 6.08 \\
\hline $11 \leq$ books $\leq 25$ & $=1$ if $11 \leq$ the number of books at home $\leq 25$ & 0.28 & 0.45 & 0.27 & 0.44 & 0.30 & 0.46 & -2.56 \\
\hline $\mathbf{2 6} \leq$ books $\leq \mathbf{1 0 0}$ & $=1$ if $26 \leq$ the number of books at home $\leq 100$ & 0.30 & 0.46 & 0.28 & 0.45 & 0.31 & 0.46 & -2.27 \\
\hline books $>100$ & $=1$ if the number of books at home $>100$ & 0.19 & 0.39 & 0.19 & 0.39 & 0.20 & 0.40 & -0.81 \\
\hline parents' occupational status & the index of the highest parental occupational status & 39.84 & 15.71 & 39.11 & 15.86 & 40.70 & 15.50 & -3.14 \\
\hline home education resources & the index of home education resources & -0.64 & 1.30 & -0.67 & 1.34 & -0.61 & 1.25 & -1.40 \\
\hline mother-science career & $=1$ if the mother has a science-related career & 0.02 & 0.13 & 0.02 & 0.13 & 0.02 & 0.12 & 0.69 \\
\hline father-science career & $=1$ if the father has a science-related career & 0.05 & 0.21 & 0.05 & 0.21 & 0.05 & 0.21 & -0.26 \\
\hline income $<0.5$ median & $=1$ if the family income $\leq 0.5$ median annual income & 0.35 & 0.48 & 0.35 & 0.48 & 0.34 & 0.47 & 1.10 \\
\hline 0.5 median $\leq$ income $<0.75$ median & $=1$ if 0.5 median $\leq$ the family income $<0.75$ median & 0.36 & 0.48 & 0.35 & 0.48 & 0.38 & 0.48 & -1.57 \\
\hline 0.75 median $\leq$ income $<$ median & $=1$ if 0.75 median $\leq$ the family income $<$ median & 0.20 & 0.40 & 0.20 & 0.40 & 0.20 & 0.40 & -0.26 \\
\hline median $\leq$ income $<1.25$ median & $=1$ if median $\leq$ the family income $<1.25$ median & 0.06 & 0.24 & 0.06 & 0.24 & 0.05 & 0.23 & 1.05 \\
\hline income $\geq 1.25$ median & $=1$ if the family income $\geq 1.25$ median & 0.03 & 0.17 & 0.03 & 0.17 & 0.03 & 0.16 & 0.55 \\
\hline
\end{tabular}


Table 1 - continued: Descriptive Statistics by Gender

\begin{tabular}{|c|c|c|c|c|c|c|c|c|}
\hline \multirow[b]{2}{*}{ Variable } & \multirow[b]{2}{*}{ Description } & \multicolumn{2}{|c|}{ Full Sample } & \multicolumn{2}{|c|}{ Male } & \multicolumn{2}{|c|}{ Female } & \multirow[b]{2}{*}{ t-Test } \\
\hline & & Mean & St. Dv. & Mean & St. Dv. & Mean & St. D. & \\
\hline \multicolumn{9}{|l|}{ School's Characteristics } \\
\hline percentage of girls & percentage of girls enrolled at school & 0.43 & 0.21 & 0.35 & 0.19 & 0.53 & 0.20 & -28.63 \\
\hline public & $=1$ if the school is public & 0.98 & 0.15 & 0.97 & 0.17 & 0.98 & 0.14 & -1.97 \\
\hline class size & $=1$ if the average class size is more than 30 at school & 0.51 & 0.50 & 0.50 & 0.50 & 0.53 & 0.50 & -1.57 \\
\hline rural & $=1$ if the school is in a rural area & 0.79 & 0.40 & 0.82 & 0.39 & 0.77 & 0.42 & 4.01 \\
\hline school education resources & ex of the quality of the school's educational resources & -0.81 & 0.92 & -0.83 & 0.91 & -0.80 & 0.93 & -0.91 \\
\hline general high school & $=1$ if the school is a general high school & 0.44 & 0.50 & 0.42 & 0.49 & 0.47 & 0.50 & -2.72 \\
\hline anatolian high school & $=1$ if the school is an anatolian high school & 0.20 & 0.40 & 0.18 & 0.39 & 0.22 & 0.41 & -2.42 \\
\hline vocational high school & $=1$ if the school is a vocational high school & 0.36 & 0.48 & 0.39 & 0.49 & 0.32 & 0.47 & 4.88 \\
\hline marmara region & $=1$ if the school is in Marmara region & 0.28 & 0.45 & 0.26 & 0.44 & 0.29 & 0.46 & -2.21 \\
\hline central anatolian region & $=1$ if the school is in Central Anatolian region & 0.21 & 0.41 & 0.21 & 0.41 & 0.21 & 0.41 & 0.16 \\
\hline aegean region & $=1$ if the school is in Aegean region & 0.14 & 0.34 & 0.13 & 0.34 & 0.14 & 0.35 & -1.15 \\
\hline mediterranean region & $=1$ if the school is in Mediterranean region & 0.11 & 0.32 & 0.10 & 0.30 & 0.13 & 0.33 & -2.45 \\
\hline blacksea region & $=1$ if the school is in Blacksea region & 0.13 & 0.33 & 0.15 & 0.35 & 0.11 & 0.31 & 3.85 \\
\hline eastern anatolian region & $=1$ if the school is in Eastern Anatolian region & 0.07 & 0.25 & 0.06 & 0.24 & 0.07 & 0.26 & -0.95 \\
\hline southeastern anatolian region & $=1$ if the school is in Southeastern Anatolian region & 0.07 & 0.25 & 0.08 & 0.28 & 0.05 & 0.21 & 4.38 \\
\hline $\mathbf{N}$ & number of observations & \multicolumn{2}{|c|}{$3 \varepsilon$} & \multicolumn{2}{|c|}{2044} & \multicolumn{2}{|c|}{1788} & \\
\hline
\end{tabular}

Notes: The last column presents t-statistics. Based on Welch's approximation, the weighted t-test compares the difference in the means of the two samples. The median annual income is $24.000 \mathrm{TL}$ in Turkey. 
Figure 1: The Mean Gender Test Score Gap in Science across OECD Countries

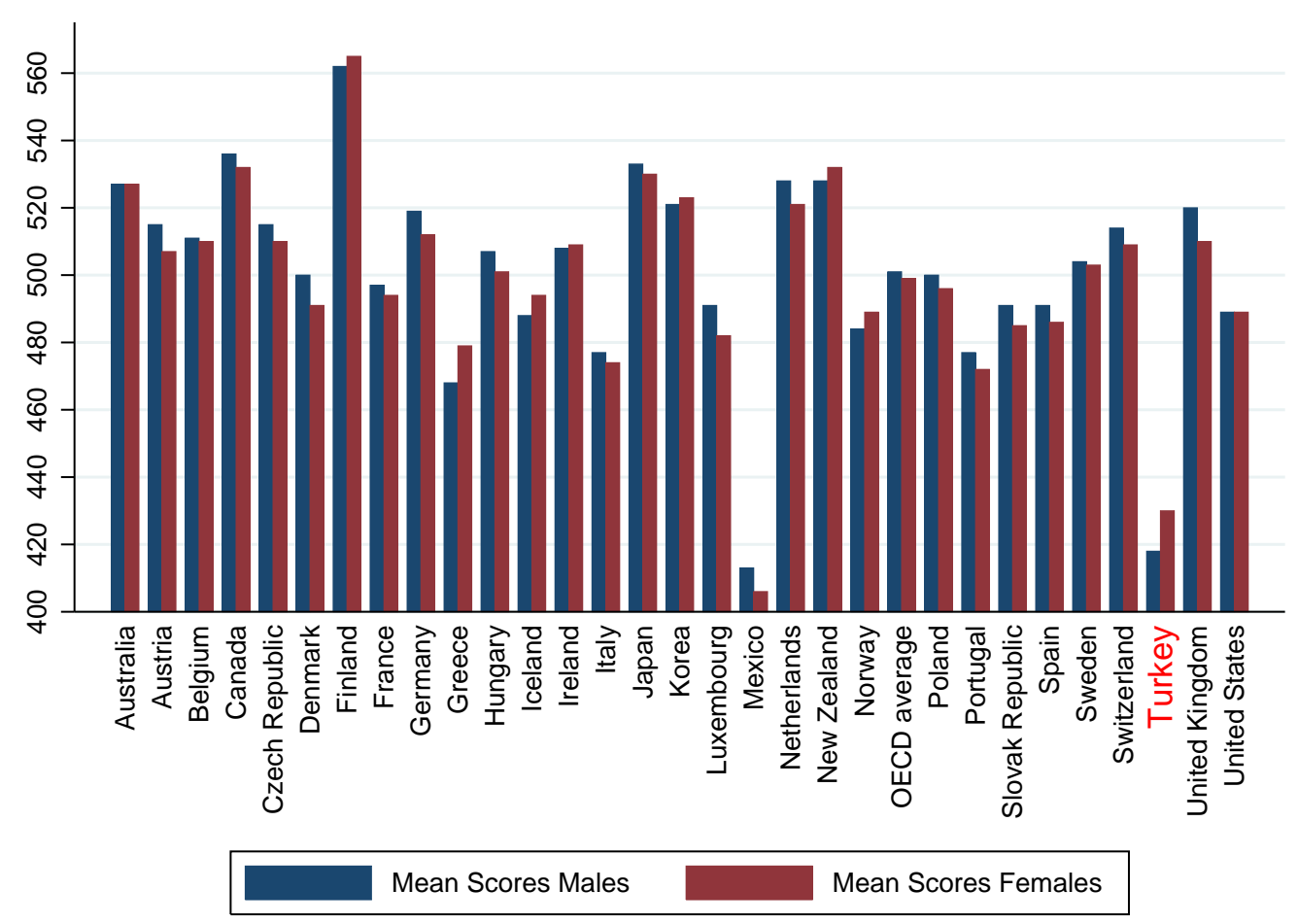

Source: OECD (2010). 
Figure 2: The Mean Gender Test Score Gap in Math across OECD Countries

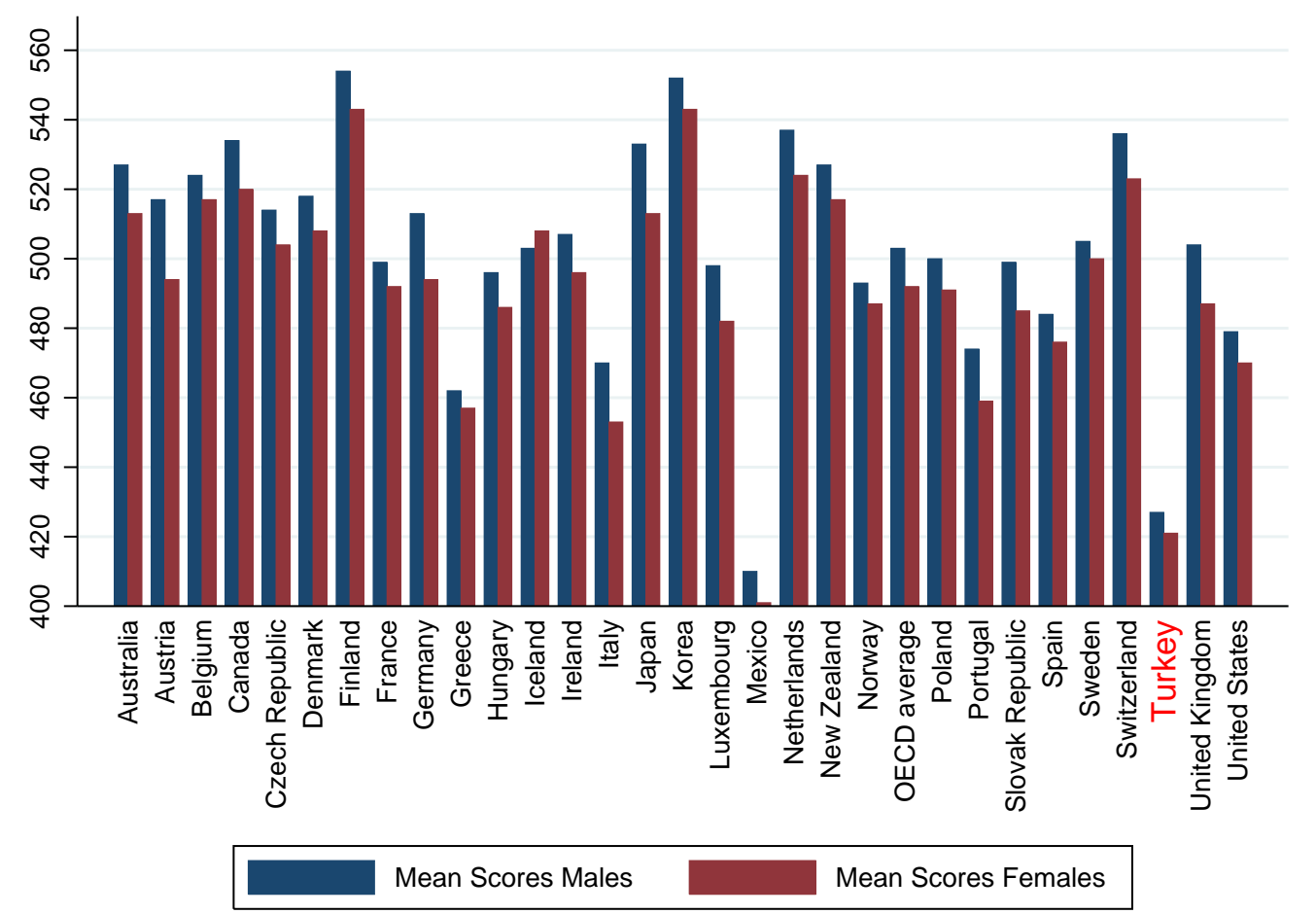

Source: OECD (2010). 
Table 2: The Index of Beliefs in Own Abilities in Science

\begin{tabular}{|c|c|c|}
\hline The index & Construction of the Index & Interpretation \\
\hline $\begin{array}{l}\text { 1- Index of self-concept } \\
\text { in science: }\end{array}$ & $\begin{array}{l}\text { It was created by using students' responses to the follow- } \\
\text { ing six statements: } \\
\text { 1. I can usually give good answers to test questions } \\
\text { on science topics } \\
\text { 2. When I am being taught science, I can understand } \\
\text { the concepts very well } \\
\text { 3. I can easily understand new ideas in science } \\
\text { 4. I learn science topics quickly } \\
\text { 5. Science topics are easy for me } \\
\text { 6. Learning advanced science } \\
\text { Response options for each statement were: strongly agree, } \\
\text { agree, disagree, and strongly disagree }\end{array}$ & $\begin{array}{l}\text { Students who agreed } \\
\text { with these statements } \\
\text { were higher on the in- } \\
\text { dex, and students who } \\
\text { reacted more negatively } \\
\text { to the statements were } \\
\text { lower on the index. }\end{array}$ \\
\hline $\begin{array}{l}\text { 2-Index of self-efficacy } \\
\text { in science: }\end{array}$ & $\begin{array}{l}\text { It was created by using students' responses to these eight } \\
\text { tasks. } \\
\text { 1. Explain why earthquakes occur more frequently } \\
\text { in some areas than in others } \\
\text { 2. Recognise the science question that underlies a } \\
\text { newspaper report on a health issue } \\
\text { 3. Interpret the scientific information provided on } \\
\text { the labelling of food items } \\
\text { 4. Predict how changes to an environment will affect } \\
\text { the survival of certain species } \\
\text { 5. Identify the science question associated with the } \\
\text { disposal of rubbish } \\
\text { 6. Describe the role of antibiotics in the treatment } \\
\text { of disease } \\
\text { 7. Identify the better of two explanations for the for- } \\
\text { mation of acid rain } \\
\text { 8. Discuss how new evidence can lead you to change } \\
\text { your understanding about the possibility of life on } \\
\text { Mars }\end{array}$ & $\begin{array}{l}\text { Students who agreed } \\
\text { they could do these } \\
\text { tasks were higher on the } \\
\text { index, and students who } \\
\text { reacted more negatively } \\
\text { were lower on the index. }\end{array}$ \\
\hline
\end{tabular}

Source: Caygill (2008). 
Table 3: The Index of Motivation in Science

\begin{tabular}{|c|c|c|}
\hline The Index & Construction of the Index & Interpretation \\
\hline $\begin{array}{l}\text { 1- Index of general inter- } \\
\text { est in science }\end{array}$ & $\begin{array}{l}\text { It was created by using students' responses to the following } \\
\text { eight statements: } \\
\text { 1. Human biology } \\
\text { 2. Topics in chemistry } \\
\text { 3. Topics in astronomy } \\
\text { 4. Topics in physics } \\
\text { 5. The biology of plants } \\
\text { 6. The ways scientists design experiments } \\
\text { 7. Topics in geology } \\
\text { 8. What is required for scientific explanations } \\
\text { Response options for each statement were: high interest, } \\
\text { medium interest, low interest, and no interest. }\end{array}$ & $\begin{array}{l}\text { Students who reported } \\
\text { higher interest were } \\
\text { higher on the index, and } \\
\text { students who were less } \\
\text { interested in the science } \\
\text { topics were lower on the } \\
\text { index. }\end{array}$ \\
\hline $\begin{array}{l}\text { 2- Index of enjoyment of } \\
\text { science }\end{array}$ & $\begin{array}{l}\text { It was created by using students' responses to the following } \\
\text { five statements: } \\
\text { 1. I enjoy acquiring new knowledge in science } \\
\text { 2. I generally have fun when I am learning science topics } \\
\text { 3. I am interested in learning about science } \\
\text { 4. I like reading about science } \\
\text { 5. I am happy doing science problems } \\
\text { Response options for each statement were: strongly agree, } \\
\text { agree, disagree, and strongly disagree. }\end{array}$ & $\begin{array}{l}\text { Students who agreed with } \\
\text { these statements were } \\
\text { higher on the index, and } \\
\text { students who reacted } \\
\text { more negatively to the } \\
\text { statements were lower on } \\
\text { the index. }\end{array}$ \\
\hline $\begin{array}{l}\text { 3- Index of instrumental } \\
\text { motivation in science }\end{array}$ & $\begin{array}{l}\text { It was created by combining students' responses to the follow- } \\
\text { ing five statements: } \\
\text { 1. I study science because I know it is useful for me } \\
\text { 2. Making an effort in my science subject(s) is worth it } \\
\text { because this will help me in the work I want to do later } \\
\text { on } \\
\text { 3. Studying my science subject(s) is worthwhile for me } \\
\text { because what I learn will improve my career prospects } \\
\text { 4. I will learn many things in my science subject(s) that } \\
\text { will help me get a job } \\
\text { 5. What I learn in my science subject(s) is worthwhile for } \\
\text { me because I need this for what I want to study later } \\
\text { on } \\
\text { Response options for each statement were: strongly agree, } \\
\text { agree, disagree, and strongly disagree. The proportions shown } \\
\text { in this table combine those who agreed and those who strongly } \\
\text { agreed. }\end{array}$ & $\begin{array}{l}\text { Students who agreed with } \\
\text { these statements were } \\
\text { higher on the index, and } \\
\text { students who reacted } \\
\text { more negatively to the } \\
\text { statements were lower on } \\
\text { the index. }\end{array}$ \\
\hline
\end{tabular}

Source: Caygill (2008). 
Figure 3: Estimated Propensity Score Distributions by Gender

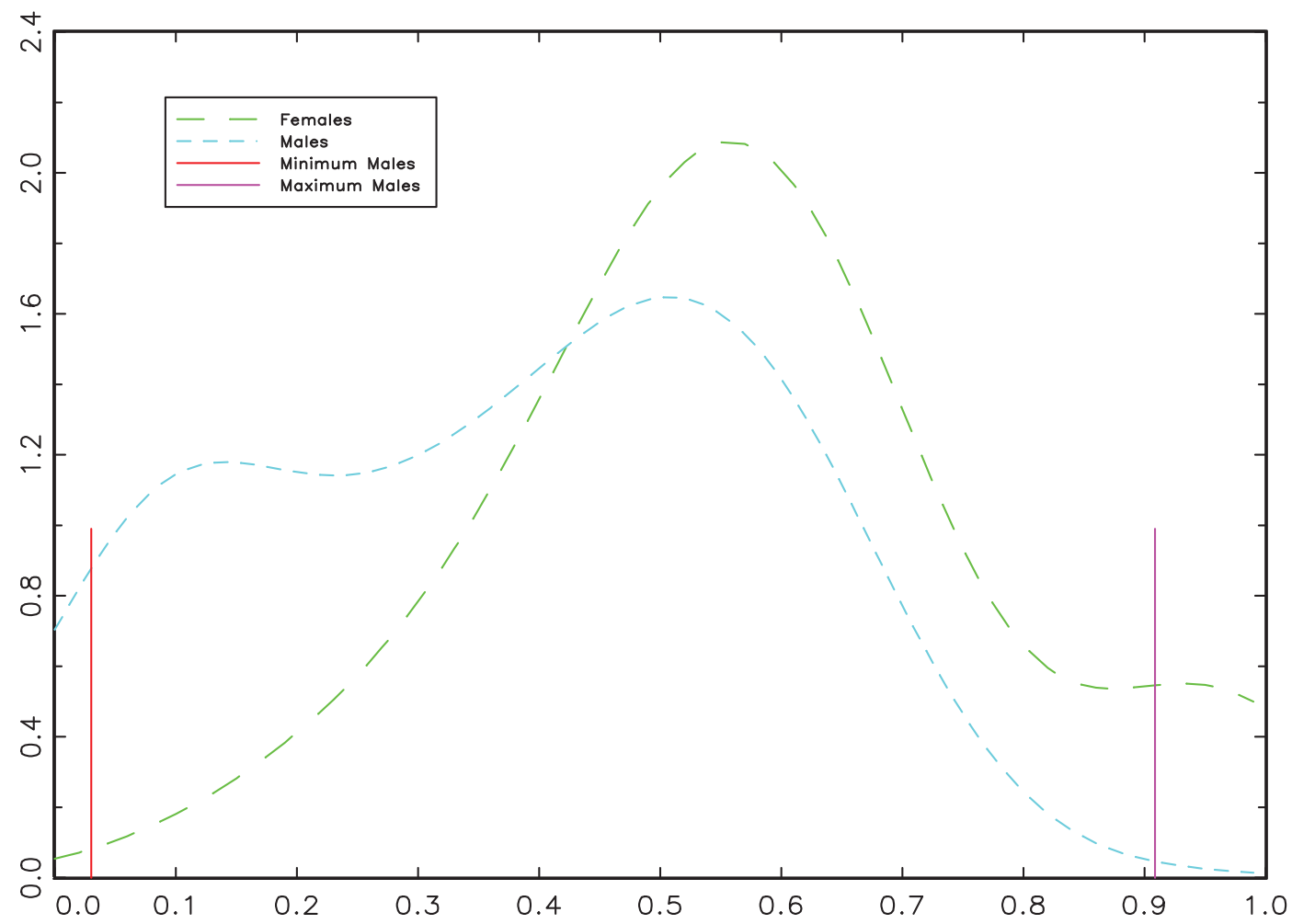

Note: Nonparametric kernel density estimate with $h=0.1$. Minimum estimated propensity score for males (females) is 0.0300 (0.0619). Maximum estimated propensity score for males (females) is $0.9086(0.9879)$. 
Table 4: OLS Estimates of the Gender Test Score Gap in Math

\begin{tabular}{|c|c|c|c|c|}
\hline & $(1)$ & $(2)$ & $(3)$ & $(4)$ \\
\hline female & $-8.669 * *$ & $-11.318^{* *}$ & $-13.583^{* *}$ & $-19.589 * *$ \\
\hline $9^{\text {th }}$ grade & & $\begin{array}{l}59.802^{* *} \\
(6.791)\end{array}$ & $\begin{array}{l}19.969^{* *} \\
(6.305)\end{array}$ & $15.273^{*}$ \\
\hline $10^{\text {th }}$ grade & & $31.552^{* *}$ & $\begin{array}{l}-1.730 \\
(6.208\end{array}$ & $16.870^{* * *}$ \\
\hline $11^{\text {th }}$ grade & & $59.378^{* *}$ & $26.042^{* *}$ & $47.482^{* *}$ \\
\hline motivation index & & $-1.641^{*}$ & -0.056 & 0.993 \\
\hline ability index & & $8.758^{* * 4}$ & $4.519^{* *}$ & $3.545^{* *}$ \\
\hline science career & & $56.017^{* *}$ & $40.328^{* *}$ & $32.127^{* * *}$ \\
\hline math is important & & $11.368^{* *}$ & $11.084^{* *}$ & $10.715^{* *}$ \\
\hline mother-primaryeduc & & & $-37.292 * *$ & $-20.397 * *$ \\
\hline mother-secondaryedu & & & $-30.143^{* *}$ & $-21.399 * *$ \\
\hline father-primaryedu & & & $-18.431^{* * *}$ & $-10.626^{*}$ \\
\hline father-secondaryedu & & & $-13.264 * *$ & $-7.969^{*}$ \\
\hline $11 \leq$ books $\leq 25$ & & & $15.371 * *$ & $7.363^{*}$ \\
\hline $26 \leq$ books $\leq 100$ & & & $24.962 * *$ & $12.986^{* *}$ \\
\hline books $>100$ & & & $26.833^{* *}$ & $12.627^{* * *}$ \\
\hline parents' occupational status & & & $0.554 * *$ & $0.473 * *$ \\
\hline educational resources & & & $9.972 * *$ & $\begin{array}{l}7.284^{* *} \\
(0.068)\end{array}$ \\
\hline mother-science career & & & $22.069^{*}$ & $17.407^{*}$ \\
\hline father-science career & & & $\begin{array}{l}2.919 \\
(5.830)\end{array}$ & $(5.2162)$ \\
\hline 0.5 median $\leq$ income $<0.75$ median & & & $5.315^{\dagger}$ & 4.704 \\
\hline 0.75 median $\leq$ income $<$ median & & & $15.951^{* *}$ & $\begin{array}{l}8.280^{* * 4} \\
3.158)\end{array}$ \\
\hline median $\leq$ income $<1.25$ median & & & $11.383^{*}$ & $8.428^{\dagger}$ \\
\hline 1.25 median $\leq$ income & & & $\begin{array}{l}-1.901 \\
(7.168)\end{array}$ & $\begin{array}{l}-2.735 \\
(6.384)\end{array}$ \\
\hline percentage of girls & & & & $10.803^{4}$ \\
\hline public & & & & -2.533 \\
\hline class size & & & & -4.111 \\
\hline rural & & & & $-15.708^{* *}$ \\
\hline school's educational resources & & & & $3.353 * 3^{*}$ \\
\hline anatolian high school & & & & $58.920 * *$ \\
\hline vocational high school & & & & $-31.021 * *$ \\
\hline central anatolian region & & & & 2.950 \\
\hline aegean region & & & & $18.365^{* *}$ \\
\hline mediterranean region & & & & $12.627^{* *}$ \\
\hline blacksea region & & & & $10.008^{* *}$ \\
\hline eastern anatolian region & & & & $-38.106^{* *}$ \\
\hline southeastern anatolian region & & & & $\begin{array}{l}-15.885^{* *} \\
(4.695)\end{array}$ \\
\hline $\begin{array}{l}N_{2} \\
R^{2}\end{array}$ & $\begin{array}{l}3832 \\
0.002\end{array}$ & $\begin{array}{l}3832 \\
0.193\end{array}$ & $\begin{array}{l}3832 \\
0.353 \\
\end{array}$ & $\begin{array}{l}3832 \\
0.491\end{array}$ \\
\hline
\end{tabular}

NOTES: The dependent variable is the PISA math score. Robust standard errors are given in parentheses. The estimations are carried out using sample weights provided in the data set. ${ }^{* *},{ }^{*}$ and ${ }^{+}$indicate that the estimated coefficients are statistically significant at the $1 \%, 5 \%$ and $10 \%$ levels respectively. Constants are not reported. The reference categories for grade, mother's education, father's education, the number of books at home, family income, school type and region are students who are in the $7^{\text {th }}$ grade or in the $7^{t h}$ grade, mothers with tertiary education, fathers with tertiary education, the number of books at home $\leq 10$, the family income $<0.5$ median family income, general high school and marmara region respectively. 
Table 5: OLS Estimates of the Gender Test Score Gap in Science

\begin{tabular}{|c|c|c|c|c|}
\hline & $(1)$ & $(2)$ & $(3)$ & $(4)$ \\
\hline female & $10.098^{* *}$ & $7.922 * *$ & $6.434^{* *}$ & 0.373 \\
\hline $9^{\text {th }}$ grade & & $61.430^{* *}$ & $28.423^{* *}$ & $28.946^{* *}$ \\
\hline $10^{\text {th }}$ grade & & $26.425^{* *}$ & $\begin{array}{l}-1.266 \\
(5.502)\end{array}$ & $\begin{array}{c}17.269^{* *} \\
(5.438)\end{array}$ \\
\hline $11^{\text {th }}$ grade & & $42.320^{* *}$ & $13.932^{1}$ & $34.363^{* *}$ \\
\hline motivation index & & -0.720 & 0.500 & $1.304^{*}$ \\
\hline ability index & & $9.817^{* *}$ & $6.338^{* * *}$ & $5.730^{* *}$ \\
\hline science career & & $44.044^{* *}$ & $31.080^{* * *}$ & $24.539 * *$ \\
\hline math is important & & $6.819 * 4$ & $6.581^{*} *$ & $6.270^{*} *$ \\
\hline mother-primaryeduc & & & $-20.482 * *$ & $\begin{array}{l}(1.481) \\
-7.708\end{array}$ \\
\hline mother-secondaryedu & & & $-17.524 * *$ & $-11.185^{*}$ \\
\hline father-primaryedu & & & $-20.103 * *$ & $-13.737^{* *}$ \\
\hline father-secondaryedu & & & $-16.770^{* *}$ & $-12.850^{* * *}$ \\
\hline $11 \leq$ books $\leq 25$ & & & $6.918^{*}$ & 0.283 \\
\hline $26 \leq$ books $\leq 100$ & & & $18.213^{* *}$ & $8.050 * 4$ \\
\hline books $>100$ & & & $25.429^{* * *}$ & $13.462 * *$ \\
\hline parents' occupational status & & & $0.400^{* * *}$ & $0.331^{* *}$ \\
\hline educational resources & & & $7.713^{* *}$ & $5.453^{*} *$ \\
\hline mother-science career & & & $18.784^{*}$ & $15.621 *$ \\
\hline father-science career & & & 4.889 & 3.711 \\
\hline 0.5 median $\leq$ income $<0.75$ median & & & $6.703^{* *}$ & $6.066^{* * *}$ \\
\hline 0.75 median $\leq$ income $<$ median & & & $15.998^{* *}$ & $9.511^{* * *}$ \\
\hline median $\leq$ income $<1.25$ median & & & $11.342^{*}$ & $8.665^{\prime \prime}$ \\
\hline 1.25 median $\leq$ income & & & $\begin{array}{l}-1.631 \\
\end{array}$ & -2.185 \\
\hline percentage of girls & & & & $14.989^{* *}$ \\
\hline public & & & & $\begin{array}{l}0.727 \\
-2.488)\end{array}$ \\
\hline class size & & & & $.586^{*}$ \\
\hline rural & & & & $-11.876 * *$ \\
\hline school's educational resources & & & & 1.799 \\
\hline anatolian high school & & & & $40.869^{* * *}$ \\
\hline vocational high school & & & & $-28.882^{* * *}$ \\
\hline central anatolian region & & & & 0.189 \\
\hline aegean region & & & & $8.909 * 4$ \\
\hline mediterranean region & & & & $9.038^{* *}$ \\
\hline blacksea region & & & & $10.041^{* * *}$ \\
\hline eastern anatolian region & & & & $-29.894 * *$ \\
\hline southeastern anatolian region & & & & $\begin{array}{c}-22.642 * * \\
(4.254)\end{array}$ \\
\hline$N$ & 3832 & 3832 & 3832 & 3832 \\
\hline$R^{2}$ & 0.004 & 0.230 & 0.365 & 0.477 \\
\hline
\end{tabular}

NOTES: The dependent variable is the PISA science score. Robust standard errors are given in parentheses. The estimations are carried out using sample weights provided in the data set. ${ }^{* *},{ }^{*}$ and ${ }^{+}$indicate that the estimated coefficients are statistically significant at the $1 \%, 5 \%$ and $10 \%$ levels respectively. Constants are not reported. The reference categories for grade, mother's education, father's education, the number of books at home, family income, school type and region are students who are in the $7^{\text {th }}$ grade or in the $7^{\text {th }}$ grade, mothers with tertiary education, fathers with tertiary education, the number of books at home $\leq 10$, the family income $<0.5$ median family income, general high school and marmara region respectively. 
Table 6: Estimates of the Responsiveness of Test Scores to Covariates by Gender

\begin{tabular}{|c|c|c|c|c|}
\hline & \multicolumn{2}{|c|}{ Math } & \multicolumn{2}{|c|}{ Science } \\
\hline & Male & Female & Male & Female \\
\hline $9^{\text {th }}$ grade & $\begin{array}{l}13.070 \\
(8.412)\end{array}$ & $19.108^{*}$ & $26.956^{* *}$ & $\begin{array}{l}32.031^{* *} \\
(8.233)\end{array}$ \\
\hline $10^{\text {th }}$ grade & $\begin{array}{l}25.616^{* *} \\
(8.214)\end{array}$ & $\begin{array}{l}11.429 \\
(8.686)\end{array}$ & $\begin{array}{l}22.858^{* *} \\
(7.324)\end{array}$ & $\begin{array}{l}14.485^{4} \\
(8.102)\end{array}$ \\
\hline $11^{\text {th }}$ grade & $\begin{array}{l}53.498 * * \\
(11.610)\end{array}$ & $\begin{array}{l}41.318 * * \\
(12.831)\end{array}$ & $\begin{array}{l}35.537^{* *} \\
(10.353)\end{array}$ & $\begin{array}{l}34.935^{* * *} \\
(11.969)\end{array}$ \\
\hline motivation index & $2.072^{*}$ & $\begin{array}{r}-0.780 \\
(0.872)\end{array}$ & $\begin{array}{l}1.503^{\dagger} \\
(0.794)\end{array}$ & $(0.866)$ \\
\hline ability index & $(1.663$ & $6.094^{* * *}$ & $5.259^{* * *}$ & $6.219^{* *}$ \\
\hline science career & $\begin{array}{l}31.131^{* *} \\
(3.622)\end{array}$ & $33.842 * *$ & $25.028^{* * *}$ & $23.573^{* *}$ \\
\hline math is important & $\begin{array}{l}11.569 * * \\
(2.162)\end{array}$ & $\begin{array}{l}10.490^{* *} \\
(2.457)\end{array}$ & $\begin{array}{l}6.752 * * \\
(1.928)\end{array}$ & $\begin{array}{l}6.116^{*} * \\
(2.292)\end{array}$ \\
\hline mother-primaryeduc & $\begin{array}{l}-20.024 * * \\
(7.164)\end{array}$ & $\begin{array}{l}-21.125^{* *} \\
(7.978)\end{array}$ & $\begin{array}{l}-3.684 \\
(6.388)\end{array}$ & $-14.222^{\dagger}$ \\
\hline mother-secondaryedu & $\begin{array}{l}-22.187^{* *} \\
(6.904)\end{array}$ & $\begin{array}{l}-18.496^{*} \\
(7.582)\end{array}$ & $\begin{array}{l}-10.496^{\dagger} \\
(6.156)\end{array}$ & $\begin{array}{l}-12.325^{\dagger} \\
(7.073)\end{array}$ \\
\hline father-primaryedu & $\begin{array}{l}-3.797 \\
(5.682)\end{array}$ & $\begin{array}{l}-16.628^{* *} \\
(6.181)\end{array}$ & $-8.8666^{\dagger}$ & $\begin{array}{l}-18.037^{* *} \\
(5.766)\end{array}$ \\
\hline father-secondaryedu & $\begin{array}{c}-0.962 \\
(5.150)\end{array}$ & $\begin{array}{l}-15.643^{* * *} \\
(5.570)\end{array}$ & $\begin{array}{l}-8.881^{\dagger} \\
(4.592)\end{array}$ & $\begin{array}{l}-17.000^{* * *} \\
(5.196)\end{array}$ \\
\hline $11 \leq$ books $\leq 25$ & $\begin{array}{l}6.8544^{\dagger} \\
(3.947)\end{array}$ & $\begin{array}{l}6.835 \\
(4330)\end{array}$ & $\begin{array}{l}-0.837 \\
(3.519)\end{array}$ & $\begin{array}{l}0.447 \\
(4.039)\end{array}$ \\
\hline $26 \leq$ books $\leq 100$ & $\begin{array}{l}11097^{* * *} \\
(4251)\end{array}$ & $12.566 * *$ & $\begin{array}{l}4.881 \\
3.790)\end{array}$ & $9670^{*}$ \\
\hline books $>100$ & $\begin{array}{l}11.201 * \\
(5.068)\end{array}$ & $\begin{array}{l}13.336^{*} \\
75.390)\end{array}$ & $\begin{array}{l}11.288^{*} \\
(4.519)\end{array}$ & $\begin{array}{l}14.580^{* * *} \\
(5.028)\end{array}$ \\
\hline parents' occupational status & $0.404^{* *}$ & $0.508^{* * 4}$ & $0.277^{* * 4}$ & $0.358^{* *}$ \\
\hline educational resources & $\begin{array}{l}5.211^{*} * \\
(1.332)\end{array}$ & $\begin{array}{l}8.941 * * \\
(1.395)\end{array}$ & $\begin{array}{l}4.510^{* * *} \\
(1.188)\end{array}$ & $5.796^{* *}$ \\
\hline mother-science career & $\begin{array}{l}21.681^{\dagger} \\
(11.648)\end{array}$ & $\begin{array}{l}12.002 \\
(12.588)\end{array}$ & $\begin{array}{l}21.008^{*} \\
(10.387)\end{array}$ & $\begin{array}{c}8.526 \\
(11.743)\end{array}$ \\
\hline father-science career & 4.239 & -2.433 & 8.490 & -1.127 \\
\hline 0.5 median $\leq$ income $<0.75$ median & $\begin{array}{l}7.866^{*} \\
(3.609)\end{array}$ & $\begin{array}{l}2.349 \\
(3.501)\end{array}$ & $\left(.020^{*}\right)$ & $\begin{array}{l}5.000 \\
(3.266)\end{array}$ \\
\hline 0.75 median $\leq$ income $<$ median & $\begin{array}{l}4.934 \\
(4.499)\end{array}$ & $\begin{array}{l}12.044^{* * *} \\
(4.337)\end{array}$ & $7.694{ }^{\dagger}$ & $11.944^{* * *}$ \\
\hline median $\leq$ income $<1.25$ median & $\begin{array}{l}8.457 \\
(6.869)\end{array}$ & $(7.5983)$ & $\begin{array}{l}12.098 * \\
(6.125)\end{array}$ & $\begin{array}{l}4.380 \\
(6.793)\end{array}$ \\
\hline 1.25 median $\leq$ income & $\begin{array}{l}-0.134 \\
(8.792)\end{array}$ & $\begin{array}{l}-3.681 \\
(9.175)\end{array}$ & $(7.839)$ & -11.285 \\
\hline percentage of girls & $\begin{array}{l}44.294^{* *} \\
(10.679)\end{array}$ & $\begin{array}{l}-23.107 * * \\
(8.683)\end{array}$ & $\begin{array}{l}54.040^{* *} \\
(9.522)\end{array}$ & $\begin{array}{l}-11.817 \\
(8.099)\end{array}$ \\
\hline public & $\begin{array}{l}6.788 \\
(9.365)\end{array}$ & $\begin{array}{l}-8.953 \\
(11.143)\end{array}$ & $\begin{array}{l}1.867 \\
(8.350)\end{array}$ & $\begin{array}{l}-4.927 \\
(10.395)\end{array}$ \\
\hline class size & $\begin{array}{l}4.412 \\
(3.990)\end{array}$ & $\begin{array}{l}-6.026 \\
(3.772)\end{array}$ & $(3.576$ & $\begin{array}{l}-7.052^{*} \\
(3.519)\end{array}$ \\
\hline rural & $-16.494^{* *}$ & $-14.361 * *$ & $\begin{array}{l}-13.711^{* *} \\
3.604)\end{array}$ & $-9.188^{* *}$ \\
\hline school's educational resources & $5.954^{* * 4}$ & $4.204^{*}$ & $4.724^{* *}$ & 1.609 \\
\hline anatolian high school & $79.456^{* *}$ & $47990^{* * *}$ & $60.012^{* * *}$ & $30.539 * *$ \\
\hline vocational high school & $-29.851 * *$ & $\begin{array}{l}-17.610^{* *} \\
-3.777)\end{array}$ & $\begin{array}{l}-21.365 * * \\
(3.782)\end{array}$ & $\begin{array}{l}-22.869^{* *} \\
(3.523)\end{array}$ \\
\hline central anatolian region & $9.906^{*}$ & $(4.843)$ & $\begin{array}{c}11.329^{* *} \\
(4.379)\end{array}$ & $\begin{array}{l}-2.860 \\
(4.163)\end{array}$ \\
\hline aegean region & $13.320^{* *}$ & $28.164^{* * *}$ & $8.175^{\dagger}$ & $14.073 * *$ \\
\hline mediterranean region & $13.843^{*}$ & $14.655^{* *}$ & $13.763^{* *}$ & 5.620 \\
\hline blacksea region & $10.490^{*}$ & $19.278^{* *}$ & $\begin{array}{l}16.139^{* *} \\
(4697)\end{array}$ & $10.722 *$ \\
\hline eastern anatolian region & $\begin{array}{l}-27.476^{* * *} \\
(6.832)\end{array}$ & $\begin{array}{l}-37.781 * * \\
(6.423)\end{array}$ & $\begin{array}{l}-12.019^{*} \\
(6.092)\end{array}$ & $\begin{array}{l}-37.011 * * \\
(5.992)\end{array}$ \\
\hline southeastern anatolian region & $\begin{array}{l}-11.273^{\dagger} \\
(6.177)^{\dagger}\end{array}$ & $\begin{array}{l}-21.796^{* *} \\
(7.437)\end{array}$ & $-12.527^{*}$ & $\begin{array}{l}-33.479^{* *} \\
(6.937)\end{array}$ \\
\hline $\begin{array}{l}N_{2} \\
R^{2}\end{array}$ & $\begin{array}{l}2044 \\
0.513\end{array}$ & $\begin{array}{l}1788 \\
0.499\end{array}$ & $\begin{array}{l}2044 \\
0.507\end{array}$ & $\begin{array}{l}1788 \\
0.466\end{array}$ \\
\hline
\end{tabular}

NOTES: In the first two columns, the dependent variable is the PISA math score while in the last two columns, it is the PISA science score Robust standard errors are indicate that the estimated coefficients are statistically significant at the $1 \%, 5 \%$ and $10 \%$ levels respectively. Constants are not reported. The reference categories for grade, mother's education, father's education, the number of books at home, family income, school type and region are students who are in the $7^{t h}$ grade or in the $7^{t h}$ grade, mothers with tertiary education, fathers with tertiary education, the number of books at home $\leq 10$, the family income $<0.5$ median family income, general high school and marmara region respectively. 
Table 7: The Standard OB Decomposition of the Gender Test Score Gap in Math

\begin{tabular}{lccccc}
\hline \hline & \multicolumn{1}{c}{$\begin{array}{c}\text { Student } \\
\text { Characteristics }\end{array}$} & $\begin{array}{c}\text { Family } \\
\text { Characteristics }\end{array}$ & $\begin{array}{c}\text { School } \\
\text { Characteristics }\end{array}$ & Constant \\
\hline Total gap & $-8.669^{* *}$ & & & & \\
& $(3.072)$ & & & & \\
Composition Effect & $17.668^{* *}$ & $2.011^{* *}$ & $1.538^{*}$ & $14.120^{* *}$ & \\
& $(2.765)$ & $(0.743)$ & $(0.734)$ & $(2.388)$ & \\
Return Effect & $-26.337^{* *}$ & -11.026 & -9.948 & $-55.596^{* *}$ & 50.233 \\
& $(3.136)$ & $(27.869)$ & $(18.127)$ & $(20.413)$ & $(39.638)$ \\
\hline \hline
\end{tabular}

NOTES: Males are treated as the reference group. Robust standard errors are given in parentheses. The estimations are carried out using sample weights provided in the data set. ${ }^{* *},{ }^{*}$ and ${ }^{+}$indicate that the estimated coefficients are statistically significant at the $1 \%, 5 \%$ and $10 \%$ levels respectively.

Table 8: The Standard OB Decomposition of the Gender Test Score Gap in Science

\begin{tabular}{lccccc}
\hline \hline & & $\begin{array}{c}\text { Student } \\
\text { Characteristics }\end{array}$ & $\begin{array}{c}\text { Family } \\
\text { Characteristics }\end{array}$ & $\begin{array}{c}\text { School } \\
\text { Characteristics }\end{array}$ & Constant \\
\hline Total gap & $10.098^{* *}$ & & & & \\
Composition Effect & $(2.731)$ & & & & \\
& $16.517^{* *}$ & $1.643^{*}$ & 0.678 & $14.196^{* *}$ & \\
Return Effect & $(2.498)$ & $(0.720)$ & $(0.631)$ & $(2.122)$ & \\
& $-6.419^{*}$ & -5.751 & -11.871 & $-54.154^{* *}$ & $65.357^{*}$ \\
& $(2.868)$ & $(22.252)$ & $(16.576)$ & $(18.481)$ & $(34.159)$ \\
\hline \hline
\end{tabular}

NOTES: Males are treated as the reference group. Robust standard errors are given in parentheses. The estimations are carried out using sample weights provided in the data set. ${ }^{* *},{ }^{*}$ and + indicate that the estimated coefficients are statistically significant at the $1 \%, 5 \%$ and $10 \%$ levels respectively.

Table 9: Semiparametric OB Decomposition of the Mean Test Score Gap for the Common Support Subpopulation

\begin{tabular}{|c|c|c|c|c|}
\hline & Characteristics & $\Delta_{c}$ & $\Delta_{r}$ & $\Delta_{S}$ \\
\hline \multirow{3}{*}{ 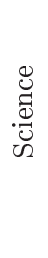 } & Student & $\begin{array}{c}0.458 \\
(2.124)\end{array}$ & $\begin{array}{l}9.739^{* *} \\
(2.731)\end{array}$ & $\begin{array}{r}10.197^{* *} \\
(2.687)\end{array}$ \\
\hline & Student + Family & $\begin{array}{l}4.306^{*} \\
(1.741)\end{array}$ & $\begin{array}{l}5.757^{*} \\
(2.404)\end{array}$ & $\begin{array}{r}10.063^{* *} \\
(2.674)\end{array}$ \\
\hline & Student + Family + School & $\begin{array}{c}19.526^{* *} \\
(2.146)\end{array}$ & $\begin{array}{l}-4.380 \\
(2.557)\end{array}$ & $\begin{array}{c}15.146^{* *} \\
(2.883)\end{array}$ \\
\hline \multirow{3}{*}{ 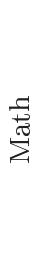 } & Student & $\begin{array}{c}2.047 \\
(2.482)\end{array}$ & $\begin{array}{c}-10.694^{* *} \\
(3.273)\end{array}$ & $\begin{array}{r}-8.647^{* *} \\
(3.053)\end{array}$ \\
\hline & Student + Family & $\begin{array}{c}6.839^{* *} \\
(1.955)\end{array}$ & $\begin{array}{c}-15.537^{* *} \\
(2.647)\end{array}$ & $\begin{array}{r}-8.698^{* *} \\
(3.049)\end{array}$ \\
\hline & Student + Family + School & $\begin{array}{c}22.169^{* *} \\
(2.408)\end{array}$ & $\begin{array}{c}-25.290^{* *} \\
(2.768)\end{array}$ & $\begin{array}{l}-3.121 \\
(3.223)\end{array}$ \\
\hline
\end{tabular}

Note: Males are always the reference group. Standard errors are in brackets and simulated with 500 bootstrap replications. ${ }^{\dagger}$ if the $5 \%$ and $95 \%$ quantile of the bootstrap distribution have the same signs, $*$ if the $2.5 \%$ and $97.5 \%$ quantile of the bootstrap distribution have the same signs, ${ }^{* *}$ if the $0.5 \%$ and $99.5 \%$ quantile of the bootstrap distribution have the same signs. 
Table 10: Semiparametric OB Decomposition of the Mean Test Score Gap

\begin{tabular}{|c|c|c|c|c|c|}
\hline & Characteristics & $\Delta_{1}$ & $\Delta_{c}$ & $\Delta_{r}$ & $\Delta$ \\
\hline \multirow{3}{*}{ 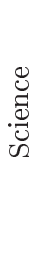 } & Student & $\begin{array}{l}-0.100 \\
(0.139)\end{array}$ & $\begin{array}{c}0.458 \\
(2.124)\end{array}$ & $\begin{array}{l}9.739^{* *} \\
(2.731)\end{array}$ & $\begin{array}{c}10.098^{* *} \\
(2.679)\end{array}$ \\
\hline & Student + Family & $\begin{array}{c}0.034 \\
(0.119)\end{array}$ & $\begin{array}{l}4.306^{*} \\
(1.741)\end{array}$ & $\begin{array}{l}5.757^{*} \\
(2.404)\end{array}$ & $\begin{array}{c}10.098^{* *} \\
(2.679)\end{array}$ \\
\hline & Student + Family + School & $\begin{array}{c}-5.048^{* *} \\
(0.735)\end{array}$ & $\begin{array}{c}19.526^{* *} \\
(2.146)\end{array}$ & $\begin{array}{l}-4.380 \\
(2.557)\end{array}$ & $\begin{array}{c}10.098^{* *} \\
(2.679)\end{array}$ \\
\hline \multirow{3}{*}{ 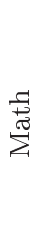 } & Student & $\begin{array}{l}-0.022 \\
(0.125)\end{array}$ & $\begin{array}{c}2.047 \\
(2.482)\end{array}$ & $\begin{array}{c}-10.694^{* *} \\
(3.273)\end{array}$ & $\begin{array}{c}-8.669^{* *} \\
(3.046)\end{array}$ \\
\hline & Student + Family & $\begin{array}{c}0.029 \\
(0.108)\end{array}$ & $\begin{array}{l}6.839^{* *} \\
(1.955)\end{array}$ & $\begin{array}{c}-15.537^{* *} \\
(2.647)\end{array}$ & $\begin{array}{c}-8.669^{* *} \\
(3.046)\end{array}$ \\
\hline & Student + Family + School & $\begin{array}{c}-5.548^{* *} \\
(0.753)\end{array}$ & $\begin{array}{c}22.169^{* *} \\
(2.408)\end{array}$ & $\begin{array}{c}-25.290^{* *} \\
(2.768)\end{array}$ & $\begin{array}{c}-8.669^{* *} \\
(3.046)\end{array}$ \\
\hline
\end{tabular}

NOTES: Males are treated as the reference group. The estimations are carried out using sample weights provided in the data set. Standard errors are given in parentheses and simulated with 500 bootstrap replications. ${ }^{\dagger}$ if the $5 \%$ and $95 \%$ quantile of the bootstrap distribution have the same signs, $*$ if the $2.5 \%$ and $97.5 \%$ quantile of the bootstrap distribution have the same signs, ${ }^{* *}$ if the $0.5 \%$ and $99.5 \%$ quantile of the bootstrap distribution have the same signs.

Table 11: Semiparametric OB Decomposition across the Distribution for the Common Support Subpopulation

\begin{tabular}{|c|c|c|c|c|c|c|}
\hline & & $\begin{array}{c}5 \% \\
\text { Quantile }\end{array}$ & $\begin{array}{c}25 \% \\
\text { Quantile }\end{array}$ & $\begin{array}{c}50 \% \\
\text { Quantile }\end{array}$ & $\begin{array}{c}75 \% \\
\text { Quantile }\end{array}$ & $\begin{array}{c}95 \% \\
\text { Quantile }\end{array}$ \\
\hline \multirow{3}{*}{ 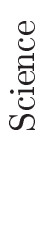 } & $\Delta_{c}$ & $\begin{array}{c}79.326^{* *} \\
(6.689)\end{array}$ & $\begin{array}{c}78.377^{* *} \\
(4.001)\end{array}$ & $\begin{array}{c}36.302^{* *} \\
(3.628)\end{array}$ & $\begin{array}{c}-19.342^{* *} \\
(4.382)\end{array}$ & $\begin{array}{c}-113.777^{* *} \\
(6.569)\end{array}$ \\
\hline & $\Delta_{r}$ & $\begin{array}{c}-66.552^{* *} \\
(6.972)\end{array}$ & $\begin{array}{c}-60.100^{* *} \\
(4.452)\end{array}$ & $\begin{array}{c}-15.415^{* *} \\
(3.269)\end{array}$ & $\begin{array}{c}35.846^{* *} \\
(3.631)\end{array}$ & $\begin{array}{c}111.352^{* *} \\
(7.233)\end{array}$ \\
\hline & $\Delta_{S}$ & $\begin{array}{c}\text { 12.775* }^{*} \\
(4.158)\end{array}$ & $\begin{array}{c}\mathbf{1 8 . 2 7 7}^{* *} \\
(3.572)\end{array}$ & $\begin{array}{c}\mathbf{2 0 . 8 8 7}^{* *} \\
(3.485)\end{array}$ & $\begin{array}{c}\mathbf{1 6 . 5 0 5}^{* *} \\
(4.256)\end{array}$ & $\begin{array}{l}\mathbf{- 2 . 4 2 4} \\
(6.710)\end{array}$ \\
\hline \multirow{3}{*}{$\frac{\frac{9}{+\pi}}{\stackrel{\pi}{\pi}}$} & $\Delta_{c}$ & $\begin{array}{c}92.304^{* *} \\
(7.560)\end{array}$ & $\begin{array}{c}83.357^{* *} \\
(4.537)\end{array}$ & $\begin{array}{c}37.701^{* *} \\
(4.146)\end{array}$ & $\begin{array}{c}-15.946^{* *} \\
(5.116)\end{array}$ & $\begin{array}{c}-124.557^{* *} \\
(8.245)\end{array}$ \\
\hline & $\Delta_{r}$ & $\begin{array}{c}-92.771^{* *} \\
(9.022)\end{array}$ & $\begin{array}{c}-85.538^{* *} \\
(4.754)\end{array}$ & $\begin{array}{c}-37.857^{* *} \\
(3.652)\end{array}$ & $\begin{array}{c}16.258^{* *} \\
(4.834)\end{array}$ & $\begin{array}{c}108.433^{* *} \\
(8.265)\end{array}$ \\
\hline & $\Delta_{S}$ & $\begin{array}{l}-0.467 \\
(5.469)\end{array}$ & $\begin{array}{l}\mathbf{- 2 . 1 8 1} \\
(4.170)\end{array}$ & $\begin{array}{l}-\mathbf{0 . 1 5 6} \\
(4.227)\end{array}$ & $\begin{array}{c}\mathbf{0 . 3 1 2} \\
(5.895)\end{array}$ & $\begin{array}{c}\mathbf{- 1 6 . 1 2 4}^{\dagger} \\
(8.355)\end{array}$ \\
\hline
\end{tabular}

NOTES: Males are treated as the reference group. The estimations are carried out using sample weights provided in the data set. Standard errors are given in parentheses and simulated with 500 bootstrap replications. ${ }^{\dagger}$ if the $5 \%$ and $95 \%$ quantile of the bootstrap distribution have the same signs, $*$ if the $2.5 \%$ and $97.5 \%$ quantile of the bootstrap distribution have the same signs, ${ }^{* *}$ if the $0.5 \%$ and $99.5 \%$ quantile of the bootstrap distribution have the same signs. 